\title{
A MALAT1/HIF-2a feedback loop contributes to arsenite carcinogenesis
}

\author{
Fei Luo ${ }^{1,2, *}$, Baofei Sun ${ }^{3, *}$, Huiqiao Li ${ }^{4, *}$, Yuan Xu1,2,5, Yi Liu1,2, Xinlu Liu ${ }^{1,2}$, Lu Lu ${ }^{1,2}$, \\ Jun $\mathbf{L i}^{3}$, Qingling Wang ${ }^{3}$, Shaofeng $\mathbf{W e i}^{3}$, Le Shi ${ }^{1,2}$, Xiaolin Lu ${ }^{1,2}$, Qizhan Liu ${ }^{1,2}$, \\ Aihua Zhang ${ }^{3}$ \\ ${ }^{1}$ Institute of Toxicology, School of Public Health, Nanjing Medical University, Nanjing 211166, Jiangsu, People's Republic of China \\ ${ }^{2}$ The Key Laboratory of Modern Toxicology, Ministry of Education, School of Public Health, Nanjing Medical University, Nanjing \\ 211166, Jiangsu, People's Republic of China \\ ${ }^{3}$ The Key Laboratory of Environmental Pollution Monitoring and Disease Control, Ministry of Education, School of Public \\ Health, Guiyang Medical University, Guiyang 550025, Guizhou, People's Republic of China \\ ${ }^{4}$ Department of Epidemiology and Biostatistics, School of Public Health, Nanjing Medical University, Nanjing 211166, Jiangsu, \\ People's Republic of China \\ ${ }^{5}$ Thoracic and GI Oncology Branch, Center for Cancer Research, National Cancer Institute, Bethesda, MD 20892, USA \\ *These authors contributed equally to this work
}

Correspondence to: Qizhan Liu, e-mail: drqzliu@hotmail.com

Aihua Zhang, e-mail: aihuagzykd@163.com

Keywords: IncRNAs, HIFs, arsenite, carcinogenesis

Received: July 16, 2015

Accepted: December 05, 2015

Published: December 31, 2015

\section{ABSTRACT}

Arsenic is well established as a human carcinogen, but the molecular mechanisms leading to arsenic-induced carcinogenesis are complex and elusive. It is also not known if IncRNAs are involved in arsenic-induced liver carcinogenesis. We have found that MALAT1, a non-coding RNA, is over-expressed in the sera of people exposed to arsenite and in hepatocellular carcinomas (HCCs), and MALAT1 has a close relation with the clinicopathological characteristics of HCC. In addition, hypoxia-inducible factor (HIF)-2a is up-regulated in HCCs, and MALAT1 and HIF-2a have a positive correlation in HCC tissues. During the malignant transformation of human hepatic epithelial (L-02) cells induced by a low concentration $(2.0 \mu \mathrm{M})$ of arsenite, MALAT1 and HIF-2a are increased. In addition, arsenite-induced MALAT1 causes disassociation of the von Hippel-Lindau (VHL) protein from HIF-2a, therefore, alleviating VHL-mediated HIF-2a ubiquitination, which causes HIF-2a accumulation. In turn, HIF- 2a transcriptionally regulates MALAT1, thus forming a positive feedback loop to ensure expression of arsenite-induced MALAT1 and HIF-2a, which are involved in malignant transformation. Moreover, MALAT1 and HIF-2a promote the invasive and metastatic capacities of arsenite-induced transformed L-02 cells and in HCC-LM3 cells. The capacities of MALAT1 and HIF-2a to promote tumor growth are validated in mouse xenograft models. In mice, arsenite induces an inflammatory response, and MALAT1 and HIF-2a are over-expressed. Together, these findings suggest that the MALAT1/HIF-2a feedback loop is involved in regulation of arsenite-induced malignant transformation. Our results not only confirm a novel mechanism involving reciprocal regulation between MALAT1 and HIF-2a, but also expand the understanding of the carcinogenic potential of arsenite. 


\section{INTRODUCTION}

Arsenite, an environmental compound with distinct physical characteristics and toxicity, is a human carcinogen that is recognized for its importance in public health [1]. Epidemiological evidence shows that chronic exposure to inorganic arsenic induces cancers, including lung, liver, and bladder cancers. It also induces neoplastic transformation of human cells, and such models have been used to investigate the mechanisms of arsenite-induced carcinogenesis. [2-4]. Transcription factors and miRNAs are involved in arsenite-induced neoplastic transformation of cells [5], but their mechanisms remain largely uninvestigated.

Hypoxia inducible factors (HIFs), HIF- $\alpha$ and HIF- $\beta$, control the expression of hundreds of genes that function in oncogenic pathways and in the regulation of proliferation, apoptosis, and tumor metabolism [6]. To date, investigations have largely focused on the regulation of protein-coding genes for these pathways [7]. However, new sequencing technologies are identifying non-coding transcripts with regulatory roles that are also relevant to cancer biology $[8,9]$. Many of these non-coding genes are also regulated by hypoxia, and, in particular, long non-coding RNAs (lncRNAs) are regulated by HIF transcriptional pathways.

lncRNAs are a new class of RNAs, with lengths ranging from $200 \mathrm{bp}$ to $100 \mathrm{kbp}$. Dysregulation of lncRNAs has been implicated in a variety of human diseases, including cancer [10]. IncRNAs contribute to transcriptional regulation by modulating the activity of transcription factors and by serving as scaffolds for assembling transcriptional regulators [11]. Post-transcriptional functions for lncRNAs are now known, with examples of lncRNAs titrating miRNAs and RNA-binding proteins, modulating mRNA decay and suppressing target mRNA translation, and functioning as a platform for protein ubiquitination [12-14].

Three lncRNAs, named HOXA transcript at the distal tip (HOTTIP) [15], highly upregulated in liver cancer (HULC), and high expressed in HCC (HEIH), have functions in hepatocellular carcinomas (HCCs) [16]. Opposite to these tumor promotion functions of lncRNAs, the lncRNA metallothionein 1D pseudogene (MT1DP) acts as a tumor suppressor, for its over-expression results in reduced cell proliferation and colony formation in soft agar and increased apoptosis in liver cancer cells [17].

Despite studies demonstrating that expression profiles for HIFs and lncRNAs correlate with tumor growth, limited information is available regarding mechanisms by which alterations in lncRNAs and HIFs contribute to initiation and early progression of arseniteinduced malignancies. In the present study, L-02 cells in culture and in animal model systems were utilized to examine lncRNA alterations mediated by arsenite. Chronic exposure of L-02 cells to arsenite induced malignant transformation and induced lncRNAs, which enhanced accumulation of HIFs. In turn, HIFs regulated transcription of lncRNAs, providing evidence for the existence of a feedback loop between HIFs and lncRNA that promotes arsenite-induced malignant transformation of L-02 cells. Further, arsenite induced over-expression of HIF- $2 \alpha$ and MALAT1 in animals and enhanced the inflammatory response. The results provide insight into the mechanisms of how lncRNAs/HIFs contribute to arsenite-induced liver carcinogenesis.

\section{RESULTS}

\section{Arsenite exposure is associated with liver and kidney damage}

Blood samples (nonpatient, $n=16$; and patient, $n=16$ ) were examined to measure the extent of exposure and to assess liver and kidney damage in those exposed to arsenite (Table 1). Relative to the control group, urinary and hair arsenite concentrations were higher $(p<0.01$, Table 1). Consistent with the difference of arsenite exposure, the albumin/globulin (A/G) ratio, an indicator of liver damage, was lower in the exposed group relative to the control group ( $p<0.01$; Table 1). In addition, the BUN levels, which indicate kidney damage, of the exposed group were higher than those for the control group ( $p<0.05$; Table 1). These results indicate that arsenite exposure is associated with liver and kidney damage.

\section{IncRNAs are over-expressed in sera of patients exposed to arsenite}

The expression of lncRNAs in sera of those exposed and not exposed to arsenite was measured. To assess candidate lncRNAs for functional studies, we determined if some common IncRNAs were differentially expressed in the sera of those exposed to arsenite. H19, HOTAIR, and MALAT1 were higher in the sera of 16 persons with long-term exposure to arsenite than in the sera of 16 controls; of the three lncRNAs, the differential expression of MALAT1 was highest (Figure 1A and 1B). These results show that some lncRNAs are over-expressed in sera of people with long-term exposure to arsenite.

\section{In HCC specimens, the levels of MALAT1 are high, and patients with lower levels of MALAT1 have longer survival times}

The expression of MALAT1 is up-regulated in cancers of the lung, breast, pancreas, liver, colon, uterus, cervix and prostate [18]. To determine if MALAT1 is differentially expressed in HCC tissues, 32 paired HCC tissues and adjacent normal tissues were analyzed for the levels of MALAT1. In HCC specimens, relative 
Table 1: Liver and kidney damage (mean \pm SD) in villagers from Guizhou Province (control and exposed groups)

\begin{tabular}{|c|c|c|c|c|c|c|c|}
\hline \multirow[b]{2}{*}{ Group } & \multicolumn{2}{|c|}{ As $($ mean \pm SD $)$} & \multicolumn{3}{|c|}{ Liver damage } & \multicolumn{2}{|c|}{ Kidney damage } \\
\hline & $\begin{array}{l}\text { Urine } \\
(\mu \mathrm{g} / \mathrm{L})\end{array}$ & Hair $(\mu \mathrm{g} / \mathrm{g})$ & $\mathbf{A} / \mathbf{G}$ & ALT (U/L) & AST (U/L) & $\begin{array}{c}\text { BUN } \\
(\mathrm{mmol} / \mathrm{L})\end{array}$ & $\begin{array}{c}\text { CREA } \\
(\mu \mathrm{mol} / \mathrm{L})\end{array}$ \\
\hline Control & $20.8 \pm 7.8$ & $0.1 \pm 0.07$ & $1.6 \pm 0.19$ & $20.9 \pm 4.9$ & $28.3 \pm 5.19$ & $4.5 \pm 0.82$ & $68.0 \pm 11.10$ \\
\hline Exposed & $\begin{array}{l}45.4 \pm \\
19.4 * *\end{array}$ & $0.4 \pm 0.2 * *$ & $\begin{array}{c}1.3 \pm \\
0.23 * *\end{array}$ & $25.1 \pm 11.80$ & $35.3 \pm 15.43$ & $5.7 \pm 1.18^{*}$ & $63.4 \pm 12.76$ \\
\hline
\end{tabular}

Abbreviations: As, arsenic; $\mathrm{A} / \mathrm{G}$, the ratio of albumin and globulin; ALT, glutamic-pyruvic transaminase; AST, glutamicoxalacetic transaminase; BUN, blood urea nitrogen; CREA, creatinine.

${ }^{* *} P<0.01$, significantly different compared with the control group. ${ }^{*} P<0.05$, significantly different compared with the control group

ICP-MS was used to measure both urinary arsenic and hair arsenic levels in all subjects.

to adjacent normal liver tissues, MALAT1 levels were up-regulated (Figure 2A). As with most solid tumors, there is a hypoxic microenvironment in HCCs [19], and HIFs are involved in the pathogenesis and pathophysiology of HCCs [20]. As determined in the present experiments, HIF-2 $\alpha$ was over-expressed in 32 paired HCC tissues compared to adjacent normal liver tissues (Supplementary Figure S1A and S1B), and there was a positive correlation between MALAT1 and HIF-2 $\alpha$ in HCC tissues (Supplementary Figure S1C). In addition, the correlations of MALAT1 expression with clinicopathological parameters (i.e., maximum diameter, TNM stage) were used to assess their clinical significance. Tumors $>3 \mathrm{~cm}$ had high MALAT1 expression (Figure 2B), and the levels of MALAT1 were higher with increasing clinical stage (Figure 2C). The clinicopathological characteristics of the patients are listed in Table 2. The levels of MALAT1 in
HCCs were not associated with other parameters, such as age $(p=0.500)$ or gender $(p=0.576)$ (Table 2$)$. These results indicate that, in HCC specimens, the levels of MALAT1 are over-expressed and that they correlate with the clinicopathological characteristics of HCC.

To determine the relationship between MALAT1 levels and the prognosis for HCC patients, the correlation between MALAT1 expression and overall survival (OS) was evaluated by Kaplan-Meier analysis. The OS at 5 years for patients with low MALAT1 expression was higher than that for those with high MALAT1 expression (Figure 2D). The longer survival for HCC patients with lower levels of MALAT1 indicates that MALAT1 is a prognostic indicator for OS of patients with HCC. The expression of MALAT1 in five cell lines derived from liver cancer cells was also examined. MALAT1 levels in the normal liver L-02 cells were lower than those in
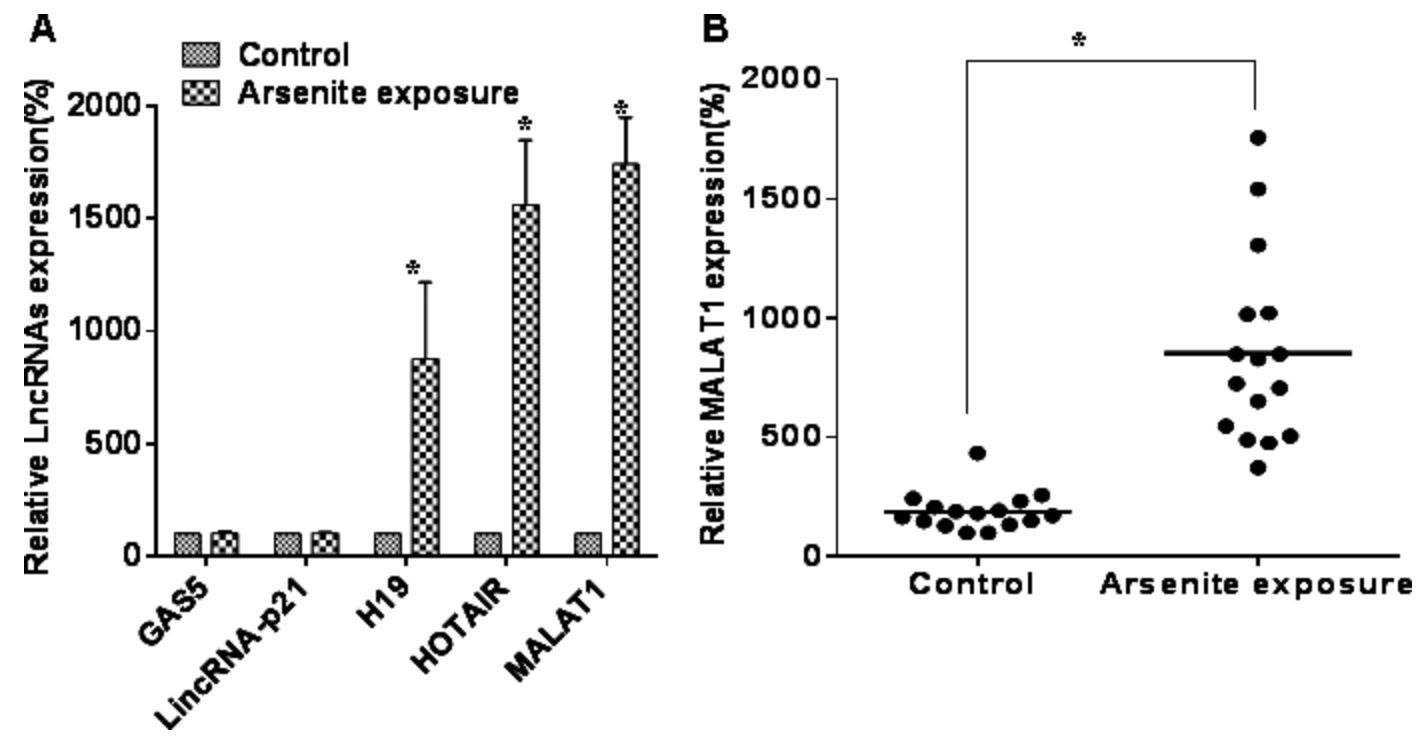

Figure 1: Some IncRNAs are over-expressed in sera of people exposed to arsenite. (A) Serum levels of lncRNAs, GAS5, lincRNA-p21, H19, HOTAIR, and MALAT1 were determined by qRT-PCR assays (means $\pm \mathrm{SD}, n=3$ ) in those exposed to arsenite $(n=16)$ or not exposed $(n=16)$. ${ }^{*} P<0.05$ different from control. (B) The levels of MALAT1 were determined by qRT-PCR assays (means $\pm \mathrm{SD}, n=3)$ in those exposed to arsenite $(n=16)$ or not exposed $(n=16) .{ }^{*} P<0.05$ different from control. 
HepG2 and Bel-7402 (weakly malignant), SMMC-7721 (moderately malignant), MHCC97H and HCC-LM3 (highly malignant) cells. Moreover, there were higher levels of MALAT1 in more aggressive cells; the highest levels were in the HCC-LM3 cells (Figure 2E). These data show that the levels of MALAT1 are differentially expressed in relation to the aggressive characteristics of liver cancer.

\section{In L-02 cells, arsenite-induced neoplastic transformation has effects on the levels of IncRNAs and HIF-2 $\alpha$}

To investigate the effects of arsenite on cell proliferation and cell transformation, L-02 cells were exposed to 1.0, 2.0, 5.0, 10.0, or $20.0 \mu \mathrm{M}$ arsenite for 24 , 48 , or $72 \mathrm{~h}$. Relative cell proliferation was increased in cells incubated with 1.0 and $2.0 \mu \mathrm{M}$ arsenite at $24 \mathrm{~h}$ but was decreased by 10.0 and $20.0 \mu \mathrm{M}$ arsenite at $48 \mathrm{~h}$ and $72 \mathrm{~h}$. There were no appreciable effects of $5.0 \mu \mathrm{M}$ arsenite on cell proliferation (Supplementary Figure S2A). Relative to the control, there was an initial increase in the growth of cells incubated with $2.0 \mu \mathrm{M}$ arsenite. Therefore, we chose $2 \mu \mathrm{M}$ arsenite for use in following experiments. L- 02 cells were exposed to 0.0 or $2.0 \mu \mathrm{M}$ arsenite for about 15 weeks (30 passages). The numbers of transformed cells increased relative to control cells (Supplementary Figure S2B).

To determine if cells chronically exposed to arsenite had acquired anchorage-independent growth capacity, their capacity for such growth was evaluated. In agar, colonies were formed by L-02 cells exposed to $2.0 \mu \mathrm{M}$ arsenite, and colonies were formed by the carcinogenic SMMC-7721 cells. In contrast, control cells showed no anchorage-independent growth (Figure $3 \mathrm{~A}$ and $3 \mathrm{~B}$ ). In addition, tumor incidences in the groups of mice injected with arsenite-transformed L-02 cells and SMMC-7721 carcinoma cells were $100 \%$ (6/6 per group); for the control group, the incidence was $0 \%(0 / 6)$. The tumor volumes for the groups implanted with arsenite-transformed cells and SMMC-7721 cells were larger. (Figure 3C and 3D).
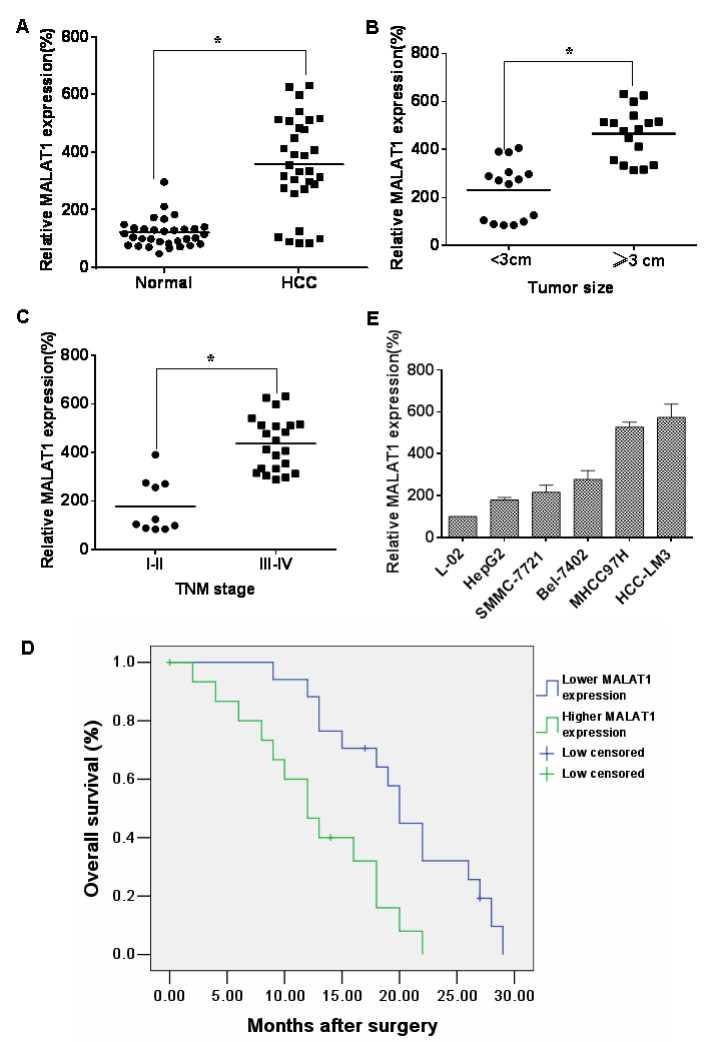

Figure 2: MALAT1 over-expression is associated with clinicopathological characteristics of HCC. (A) The levels of MALAT1 in HCC tissues $(n=32)$ and in paired adjacent normal tissues $(n=32)$ were determined by qRT-PCR assays (means \pm SD, $n=3)$ ${ }^{*} P<0.05$ different from adjacent normal tissues. (B) The levels of MALAT1 were determined by qRT-PCR assays (means \pm SD, $n=3$ ) in tumors $<3 \mathrm{~cm}(n=15)$ and in tumors $\geq 3 \mathrm{~cm}(n=17)$. ${ }^{*} P<0.05$, different from tumors $<3 \mathrm{~cm}$. (C) The mRNA levels of MALAT1 (means $\pm \mathrm{SD}, n=3)$ in tumors of patients with clinical stage I-II $(n=10)$ and with clinical stage III-IV $(n=22)$ were measured by qRT-PCR assays. ${ }^{*} P<0.05$, different from clinical stages I-II. Kaplan-Meier curves were constructed for survival of patients with HCC cancers divided according to the levels of MALAT1. (D) There were significantly $(P=0.005)$ shorter survival times for patients with high MALAT1 levels than for those with low MALAT1 levels. (E) The MALAT1 levels were determined by qRT-PCR (means \pm SD, $n=3$ ) for HCC cell lines (HepG2, SMMC-7721, Bel-7402, MHCC97H, and HCC-LM3) with different aggressive characteristics. L-02 cells were used as control cells. 
Table 2: Correlation between the levels of MALAT1 and the clinicopathological characteristics of HCC

\begin{tabular}{|c|c|c|c|}
\hline \multirow{2}{*}{ Characteristic } & \multicolumn{3}{|c|}{ MALAT1 } \\
\hline & $\operatorname{High}(N=15)$ & Low $(N=17)$ & $P$ \\
\hline \multicolumn{4}{|l|}{ Age (years) } \\
\hline$\leqq 50$ & 7 & 9 & 0.500 \\
\hline$>50$ & 8 & 8 & \\
\hline \multicolumn{4}{|l|}{ Gender } \\
\hline Male & 12 & 13 & 0.576 \\
\hline Female & 3 & 4 & \\
\hline \multicolumn{4}{|l|}{ HBsAg $^{\mathrm{a}}$} \\
\hline Positive & 13 & 14 & 0.563 \\
\hline Negative & 2 & 3 & \\
\hline $\operatorname{Serum} \operatorname{AFP}^{b}(\mathrm{ng} / \mathrm{ml})<200$ & 1 & 5 & 0.116 \\
\hline > 2001115 & 11 & 15 & \\
\hline \multicolumn{4}{|l|}{ Cirrhosis } \\
\hline Yes & 13 & 12 & 0.254 \\
\hline No & 2 & 5 & \\
\hline \multicolumn{4}{|l|}{ Tumor size } \\
\hline$<3 \mathrm{~cm}$ & 3 & 12 & $0.005 *$ \\
\hline$\geq 3 \mathrm{~cm}$ & 12 & 5 & \\
\hline \multicolumn{4}{|l|}{ Multinodular tumor } \\
\hline Yes & 12 & 9 & 0.108 \\
\hline No & 3 & 8 & \\
\hline \multicolumn{4}{|l|}{ TNM stage } \\
\hline I-II & 1 & 9 & $0.006^{*}$ \\
\hline III-IV & 14 & 8 & \\
\hline
\end{tabular}

${ }^{\mathrm{a}} \mathrm{HBsAg}$ : surface antigen of the hepatitis B virus.

${ }^{\mathrm{b} A F P}: \alpha$-fetoprotein, a marker for liver cancer. $* P<0.05$.

The expressions of various lncRNAs in L-02 cells exposed to 0.0 or $2.0 \mu \mathrm{M}$ arsenite for $0,10,20$, or 30 passages were assessed. MALAT1, H19, and HOTAIR were increased in arsenite-transformed L-02 cells, and their expressions increased with increased numbers of passages (Figure 3E). Similar to our previous results showing that expression of HIF-2 $\alpha$ is induced in human bronchial epithelial cells exposed to arsenite [4], we demonstrated that HIF- $2 \alpha$ is up-regulated in HCC tissues. We also determined that HIF- $2 \alpha$ expression in L-02 cells increases with increased numbers of passages in the presence of arsenite (Figure 3F). The expressions of MALAT1, H19, and HOTAIR increased after arsenite exposure over periods ranging from 0 to $24 \mathrm{~h}$ (Figure $3 \mathrm{G}$ ). Over $24 \mathrm{~h}$, the levels of HIF-2 $\alpha$ were also increased by arsenite (Figure 3H). Furthermore, HIF-2 $\alpha$ was expressed in L-02 cells exposed for $12 \mathrm{~h}$ to DFX, an iron chelator used to mimic hypoxia [21] (Figure 3H). Thus, a low level of arsenite induces malignant transformation of L-02 cells and up-regulates MALAT1 and HIF- $2 \alpha$.

\section{Effect of MALAT1 on the degradation of HIF-2 $\alpha$ in $\mathrm{L}-02$ cells exposed to arsenite}

We next determined if MALAT1 mediates HIF- $2 \alpha$ expression. After transfection of L-02 cells exposed to arsenite for $24 \mathrm{~h}$ with MALAT1-specific siRNA1, siRNA2, or siRNA3, levels of MALAT1 mRNA decreased (Supplementary Figure S3A and S3B). Of these, siRNA3 was more efficient, and it was applied in 
further experiments. In L-02 cells exposed to arsenite, HIF- $2 \alpha$ mRNA levels were not affected, however, there was a decrease of HIF- $2 \alpha$ protein expression and of HIF$2 \alpha$ gene targets; mRNA levels of VEGF and Oct4 were decreased by knockdown of MALAT1 (Figure 4A). These results indicate that HIF-2 $\alpha$ accumulation mediated by MALAT1 upon arsenite exposure occurs at the posttranscriptional level. Then, we found that arsenite could stable HIF-2 $\alpha$ protein in the cellular (Supplementary Figure S3C and S3D). Next, in the arsenite-treated cells transfected with control siRNA, the levels of HIF- $2 \alpha$ protein decreased slowly. In contrast, in the MALAT1transfected cells, the HIF-2 $\alpha$ protein had a shorter half-life and was barely detectable at $30 \mathrm{~min}$ (Figure 4B and 4C).

To determine if the faster reduction of HIF- $2 \alpha$ protein in MALAT1-inhibited cells was associated with its proteasome-dependent degradation. The reduction of HIF-2 $\alpha$ caused by MALAT1 knockdown was reversed by MG132 (Figure 4D). Since hydroxylation of the HIF-2 $\alpha$ protein at proline residue 531 is required for VHL binding and subsequent degradation through the ubiquitinproteasome pathway [22], the effect of MALAT1 on hyp531 HIF-2 $\alpha$ levels was determined. MALAT1 knockdown led to an increase in hyp531 HIF-2 $\alpha$ levels in L-02 cells exposed to arsenite (Figure 4E). Further, knockdown of MALAT1 attenuated arsenite-reduced HIF- $2 \alpha$ polyubiqutination (Figure 4F). Moreover, knockdown of MALAT1 enhanced the HIF-2 $\alpha$-VHL interaction in L-02 cells exposed to arsenite (Figure 4G). Together, these results indicate that arsenite-induced MALAT1 causes disassociation of VHL from HIF- $2 \alpha$, thereby alleviating VHL-mediated HIF-2 $\alpha$ ubiquitination and subsequent degradation.

\section{MALAT1 is a transcriptional target of HIF-2 $\alpha$ in L-02 cells exposed to arsenite}

In endothelial cells, hypoxia increases MALAT1, which controls a phenotypic switch [23]. We hypothesized that MALAT1 is regulated by HIF- $2 \alpha$. To establish this, HIF-2 $\alpha$ was knocked down in L-02 cells exposed to arsenite. In these cells, knockdown of HIF-2 $\alpha$ attenuated arseniteinduced MALAT1 up-regulation (Figure 5A). Conversely, ectopic expression of HIF-2 $\alpha$ increased MALAT1 expression equivalent to arsenite-induced MALAT1 upregulation (Figure 5B). These data indicate that HIF-2 $\alpha$ is responsible for arsenite-induced MALAT1 expression.
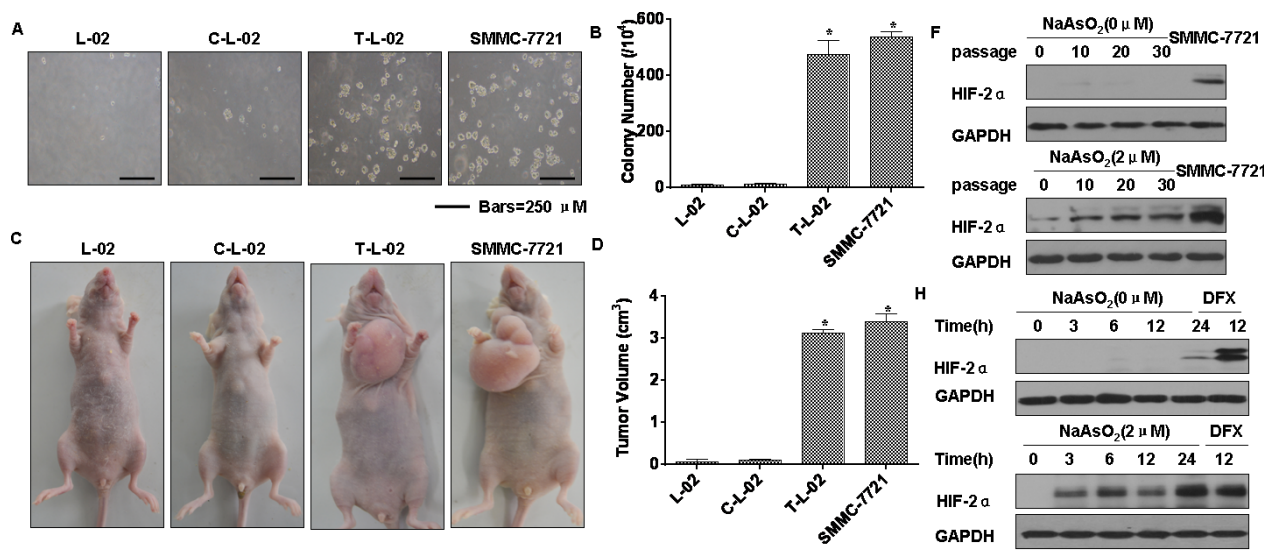

E
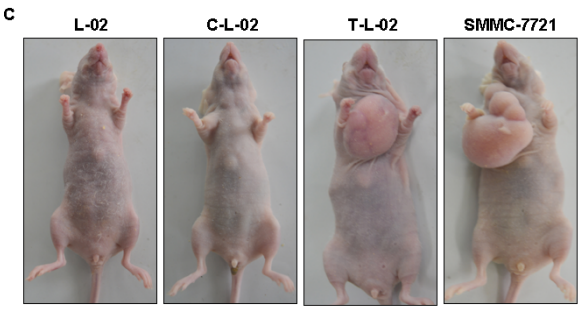

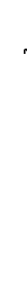

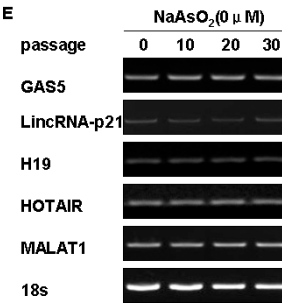
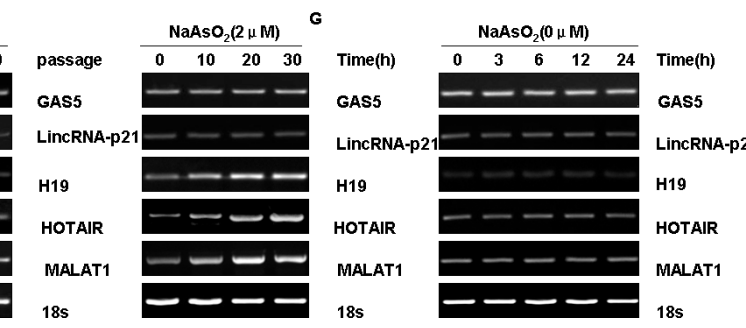

$\mathrm{NaAsO}_{2}(2 \mu \mathrm{M})$

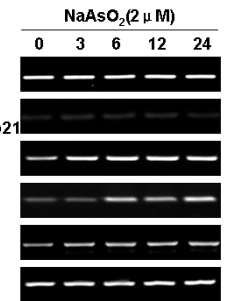

Figure 3: Arsenite-induced neoplastic transformation has effects on the levels of IncRNAs and HIF-2 $\alpha$ in L-02 cells. Abbreviations: $L-02$, normal L-02 cells, $C$ - L-02, passage controlL-02 cells; T-L-02, arsenite-transformedL-02 cells; SMMC-7721, SMMC-7721 carcinoma cells. Densities of bands were quantified by Eagle Eye II software. GAPDH levels, measured in parallel, served as controls. L-02 cells were exposed to 0.0 or $2.0 \mu \mathrm{M}$ of arsenite for 30 passages. (A) Colonies of normal L-02 cells, passage control L-02 cells, arsenitetransformed L-02 cells, and SMMC-7721 cells and their numbers (B) (means $\pm \mathrm{SD}, n=3$ ) in soft agar (bars $=250 \mu \mathrm{m}) .{ }^{*} P<0.05$ different from medium control cells. (C) At 4 weeks after inoculation of normal L-02 cells, passage control L-02 cells, arsenite-transformed L-02 cells, and SMMC-7721 cells, tumors that formed from the transformed cells and SMMC-7721 cells were examined, and their volumes (D) were measured (means $\pm \mathrm{SD}, n=6$ ). ${ }^{*} P<0.05$ different from medium control cells. L- 02 cells were exposed to 0.0 or $2.0 \mu \mathrm{M}$ of arsenite for 0, 10, 20, or 30 passages. (E) RT-PCR analyses of the mRNA levels of GAS5, lincRNA-p21, H19, HOTAIR, and MALAT1. (F) Western blots for HIF-2 $\alpha$ were made for L-02 cells exposed to 0.0 or $2.0 \mu \mathrm{M}$ arsenite for $0,3,6,12$, or $24 \mathrm{~h}$. (G) RT-PCR was performed for GAS5, lincRNA-p21, H19, HOTAIR, and MALAT1, and (H) Western blots for HIF-2 $\alpha$ were made. 
We next determined if HIF-2 $\alpha$ regulates MALAT1 expression at the transcriptional level. The genomic sequence upstream of the gene coding for MALAT1 was inspected by use of the Genomatix suite of sequence analysis tools (MatInspector). Three putative hypoxia response elements (HREs, 5'-RCGTG-3') were found within the promoter of the MALAT1 gene (Figure 5C). Chromatin immunoprecipitation (ChIP) assays were used to determine the association of HIF-2 $\alpha$ and the chromatin fragments corresponding to the three HREs within the MALAT1 gene. For L-02 cells exposed to arsenite, the antibody against HIF- $2 \alpha$ immunoprecipitated DNA fragments containing the potential binding site, which was the third HRE, not the first and the second HREs in the promoter regions of MALAT1 (Figure 5D). We also confirmed an interaction of HIF-2 $\alpha$ with the third HRE of MALAT1 promoter regions in HCC-LM3 cells (Supplementary Figure S4A). In addition, we evaluated whether the HREs within the MALAT1 gene confer HIF-2 $\alpha$-dependent transcriptional activity. Since the first and second HREs were close, one reporter plasmid containing the two HREs was constructed and designated as MALAT1-P1; the other one was designated as MALAT1-P2. DNA fragments containing wildtype or mutant HREs were inserted into the promoter region of a luciferase reporter plasmid. The result was that luciferase expression from MALAT1-P2, but not from the MALAT1-P1 reporter or the mutant reporter, was decreased by inhibiting expression of HIF-2 $\alpha$ (Figure 5E and 5F). In contrast, luciferase expression from MALAT1-P2, but not the MALAT1-P1 reporter or the mutant reporter, was induced by arsenite and by ectopic expression of HIF-2 $\alpha$ (Figure $5 \mathrm{G}$ and $5 \mathrm{H}$ ). These results demonstrate that MALAT1 is transcriptionally upregulated by HIF- $2 \alpha$ in L-02 cells exposed to arsenite.

\section{MALAT1 and HIF-2 $\alpha$ are involved in the arsenite-induced malignant transformation of L-02 cells}

Since MALAT1 and HIF-2 $\alpha$ are over-expressed in arsenite-transformed L-02 cells (Figure 3), the functions of MALAT1 and HIF-2 $\alpha$ during arsenite-induced malignant transformation, an early step in liver carcinogenesis, were examined. Arsenite-transformed L-02 cells were transduced with lentivirus-mediated sh-MALAT1 or sh-RNA negative control (shRNA-NC) vectors. The transduced cells were detected as green fluorescent protein (GFP)-positive cells following the addition of GFP together with the MALAT1 shRNAs. The expression of

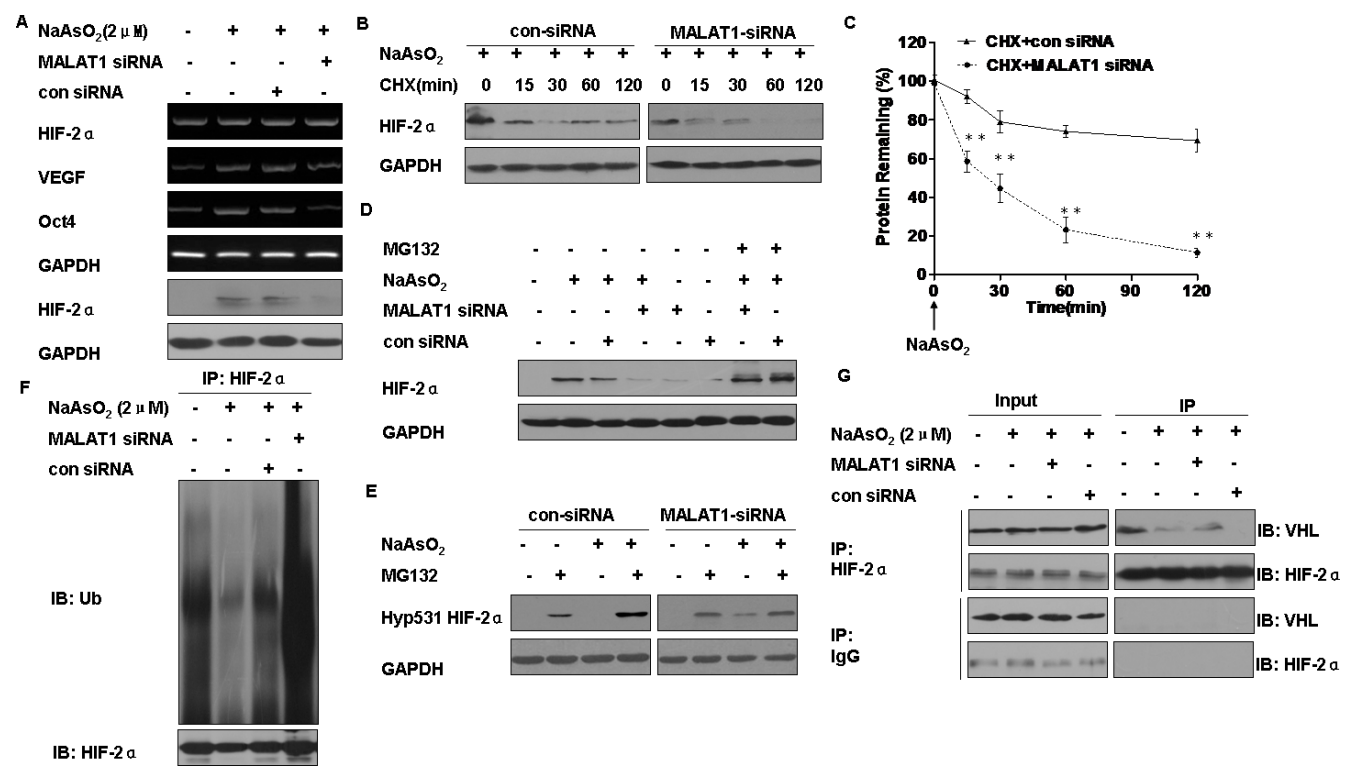

Figure 4: Functions of MALAT1 in the degradation of HIF-2 $\alpha$ in L-02 cells exposed to arsenite. L-02 cells were exposed to $100 \mathrm{ppm}$ of control siRNA or MALAT1 siRNA for $24 \mathrm{~h}$, then incubated with 0.0 or $2.0 \mu \mathrm{M}$ arsenite for $24 \mathrm{~h}$. (A) The mRNA levels of HIF-2 $\alpha$, Oct-4, and VEGF were measured by RT-PCR, and Western blots of HIF-2 $\alpha$ were made. L-02 cells were exposed to 100 ppm of control siRNA or MALAT1 siRNA for $24 \mathrm{~h}$, then exposed to $2.0 \mu \mathrm{M}$ arsenite for $24 \mathrm{~h}$ before they were treated with the protein synthesis inhibitor, CHX $(20 \mu \mathrm{g} / \mathrm{ml})$ for the indicated periods of time. (B) Western blots were made, and (C) protein expression (means $\pm \mathrm{SD}$, $n=3$ ) of HIF-2 $\alpha$ was determined. ${ }^{* *} P<0.01$ different from cells treated with control siRNA. L-02 cells were treated with control siRNA or MALAT1 siRNA for $24 \mathrm{~h}$ then exposed to 0.0 or $10.0 \mu \mathrm{M}$ proteasome inhibitor MG132 in the absence or presence of $2.0 \mu \mathrm{M}$ arsenite for 24 h. (D) The levels of HIF-2 $\alpha$ were analyzed by Western blots. (E) The levels of Hyp531 HIF-2 $\alpha$ were analyzed by Western blots. L-02 cells were exposed to $100 \mathrm{ppm}$ of control siRNA or MALAT1 siRNA for $24 \mathrm{~h}$, then incubated with 0.0 or $2.0 \mu \mathrm{M}$ arsenite for $24 \mathrm{~h}$. (F) The levels of HIF-2 $\alpha$ were determined by Western blots after total protein of cells was subjected to co-immunoprecipitation with HIF-2 $\alpha$ (IP) and ubiquitin (IB) antibodies. (G) Western blot analyses of HIF-2 $\alpha$ and VHL after cell lysates were subjected to co-immunoprecipitation with HIF-2 $\alpha$ (IP) and VHL (IB) antibodies. 
the lentivirus-mediated MALAT1 shRNAs was confirmed by fluorescence imaging (Figure 6A). The level of MALAT1 detected by qRT-PCR was reduced following transduction by MALAT1 shRNAs compared with that in the arsenite-transformed L-02 cells and shRNA-NCtransduced cells (Figure 6B). These findings confirmed that the lentivirus-mediated transduction of the MALAT1 shRNAs were effective. Incubated under anchorageindependent conditions, the T-L02-sh-NC cells produced an elevated number of large colonies, but cells silenced for MALAT1 formed only a few colonies, and these were of small size (Figure 6C, upper, and 6D). To determine if MALAT1 facilitates migration and invasion of arsenitetransformed L-02 cells, invasion through Matrigel and migration through Transwells were evaluated. Relative to controls, inhibition of MALAT1 impeded the invasion and migration of arsenite-transformed L-02 cells (Figure 6C, below, and 6E). These effects of MALAT1 on malignant and metastatic capacity were confirmed in HCC-LM3 cells, which were also transfected with lentivirus sh-MALAT1 (Supplementary Figure S5A, S5B, S5C, $\mathrm{S} 5 \mathrm{D}$, and S5E). Moreover, MALAT1-knockdown cells were injected into nude mice. MALAT1 knockdown decreased the sizes of tumors that developed relative to the arsenite-treated group (Figure 6F and 6G). MALAT1 knockdown, however, did not change the incidence rate. In addition, the lentivirus-negative vector (sh-NC) and shHIF-2 $\alpha$ were transfected into arsenite-transformed L-02 cells. At post-transfection, fluorescent microscopy showed emission of green fluorescence (Figure 6H). qRT-PCR showed that expression of HIF-2 $\alpha$ level was decreased in sh- HIF-2 $\alpha$-transfected, arsenite-transformed L-02 cells (T-L-02-sh-HIF-2 $\alpha$ cells), compared to control cells (Figure 6I). Silencing of HIF-2 $\alpha$ reduced the formation

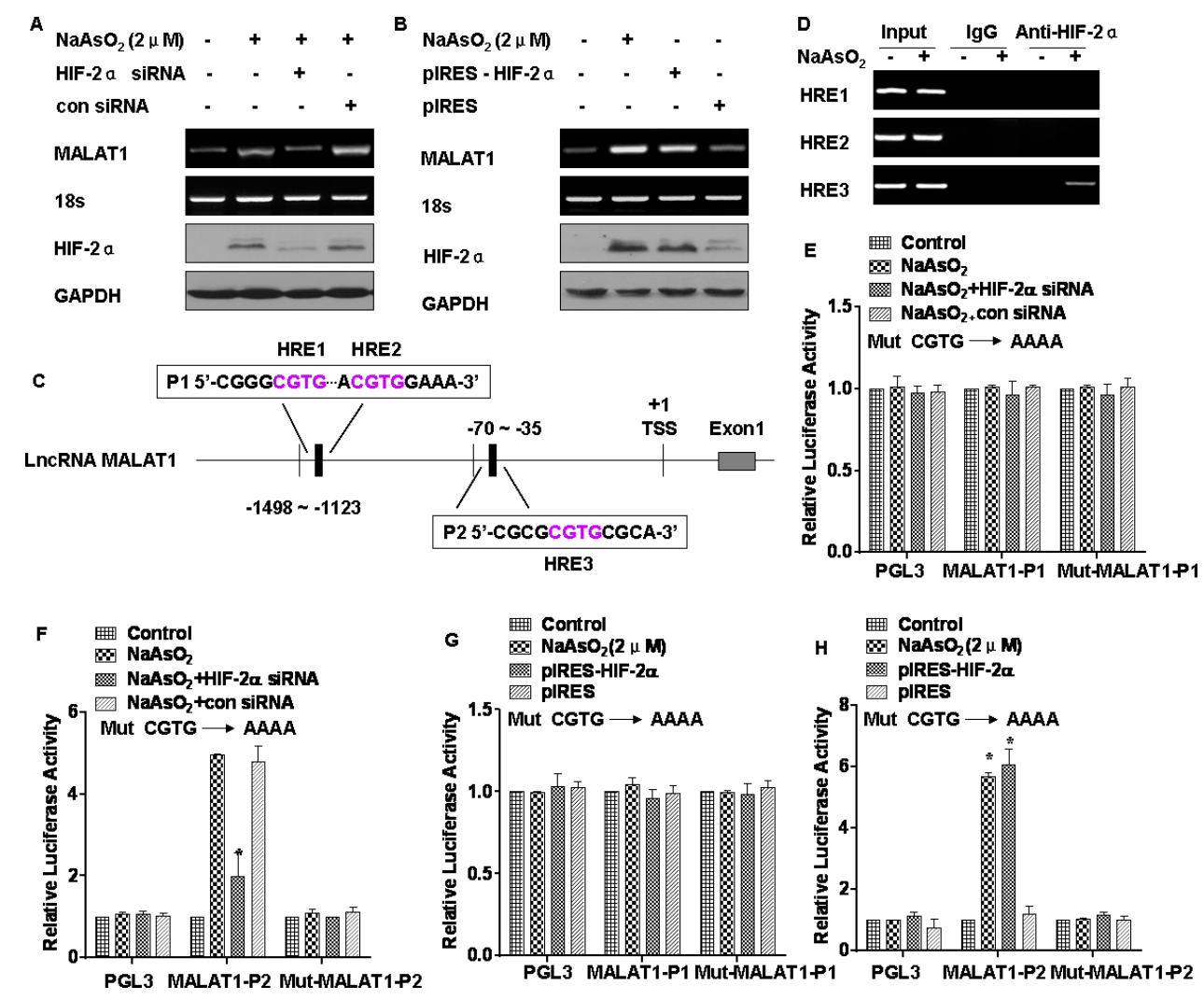

Figure 5: MALAT1 is regulated by HIF-2 $\alpha$ in L-02 cells exposed to arsenite. GAPDH or 18 s ribosomal RNA, measured in parallel, served as controls. L-02 cells were exposed to $20 \mathrm{nM}$ of control siRNA or to $10 \mathrm{nM} \mathrm{HIF-2} \alpha$ siRNA for $24 \mathrm{~h}$, and then incubated with 0.0 or $2.0 \mu \mathrm{M}$ arsenite for $24 \mathrm{~h}$. (A) The mRNA levels of MALAT1 were determined by RT-PCR, and the levels of HIF- $2 \alpha$ were analyzed by Western blot analyses. L-02 cells were transfected with the HIF-2 $\alpha$ plasmid for $24 \mathrm{~h}$, then incubated with 0.0 or $1.0 \mu \mathrm{M}$ arsenite for $24 \mathrm{~h}$. (B) The mRNA levels of MALAT1 were determined by RT-PCR, and the levels of HIF-2 $\alpha$ were analyzed by Western blot analyses. (C) Schematic illustration of the consensus HIF- $2 \alpha$ HREs in the MALAT1 gene promoter. L- 02 cells were treated with 0.0 or $2.0 \mu \mathrm{M}$ arsenite for $24 \mathrm{~h}$. (D) The binding of HIF-2 $\alpha$ to promoters of MALAT1, three domains of HRE, was measured by a ChIP assay after the chromatin was immunoprecipitated with antibodies against HIF-2 $\alpha$. L-02 cells were co-transfected with HIF-2 $\alpha$ siRNA and reporter constructs for $24 \mathrm{~h}$, then incubated with 0.0 or $1.0 \mu \mathrm{M}$ arsenite for $24 \mathrm{~h}$. (E) Luciferase activities of MALAT1-P1 and Mut-MALAT1-P1, and (F) MALAT1-P2 and Mut-MALAT1-P2 were measured and normalized to Renilla luciferase activity (means $\pm \mathrm{SD}, n=3$ ); $* P<0.05$ different from control cells treated with arsenite. L-02 cells were co-transfected with the HIF-2 $\alpha$ plasmid and reporter constructs for $24 \mathrm{~h}$, then incubated with 0.0 or $1.0 \mu \mathrm{M}$ arsenite for $24 \mathrm{~h}$. (G) Luciferase activities of MALAT1-P1 and Mut-MALAT1-P1, and (H) MALAT1-P2 and Mut-MALAT1-P2 were measured and normalized to Renilla luciferase activity (means $\pm \mathrm{SD}, n=3$ ); ${ }^{*} P<0.05$ different from control cells. 


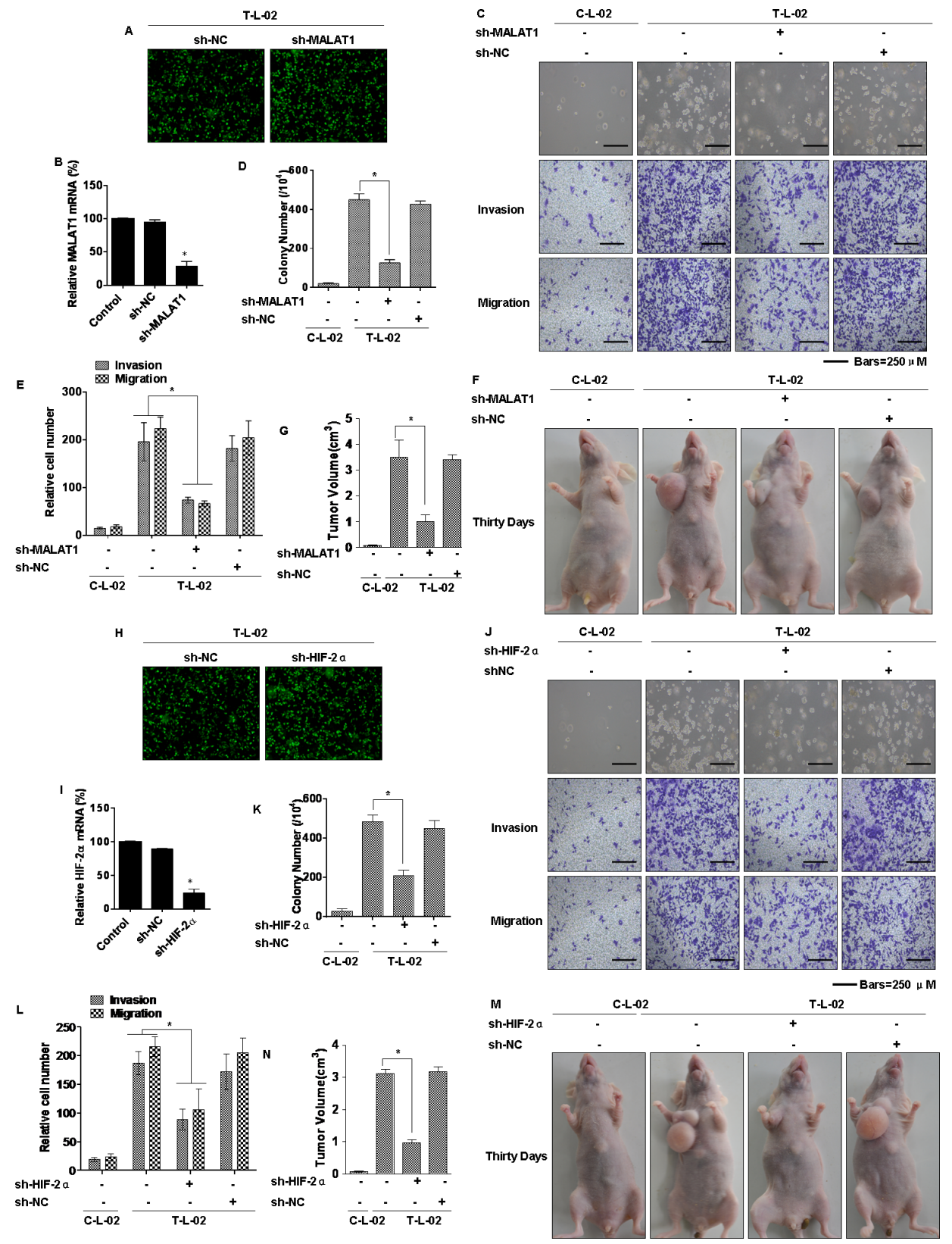

Figure 6: Influence of MALAT1 and HIF-2 $\alpha$ on the neoplastic capacity of transformed L-02 cells. Abbreviations: $C$ - $L-02$, passage control L-02 cells; T-L-02, arsenite-transformed L-02 cells. T-L-02 cells were infected with a non-targeting control vector (sh-NC) or MALAT1 shRNA (sh-MALAT1), inducing puromycin resistance. Cells were cultured for at least 2 weeks in the presence of puromycin $(5 \mu \mathrm{g} / \mathrm{mL})$ before the following experiments. (A) T-L-02/shNC cells and T-L-02/sh-MALAT1 cells. Fluorescent microscopy. Sh-MALAT1 and sh-NC were transfected into T-L-02 cells. At $24 \mathrm{~h}$ after transfection, fluorescent microscopy showed emission green fluorescence. (B) qRT-PCR validated the downregulation of MALAT1 after shRNA knockdown in T-L-02 cells, ${ }^{*} P<0.05$ different from T-L-02 cells. (C) Colony formation was assessed in soft agar (above), and representative images of cells migration and cell invasion (middle and bottom) and (D) their colony numbers and (E) relative migrating/invading cells (means $\pm \mathrm{SD}, n=3$ ) were quantified, bars $=250 \mu \mathrm{m}$. ${ }^{*} P<0.05$ different from T-L-02 cells. $1 \times 10^{7}$ cells were injected into nude mice $(n=6)$. (F) Tumor volumes were determined $(\mathbf{G})$ at 4 weeks after injection, $(n=6$, mean $\pm \mathrm{SD}),{ }^{*} P<0.05$ different from T-L-02 cells. T-L-02 cells were infected with a non-targeting control vector (sh-NC) or HIF-2 $\alpha$ shRNA (sh-HIF-2 $\alpha$ ), inducing puromycin resistance. Cells were cultured for at least 2 weeks in the presence of puromycin $(5 \mu \mathrm{g} / \mathrm{mL})$ before the following experiments. (H) T-L-02/sh-NC cells and T-L-02/sh-HIF-2 $\alpha$ cells. Fluorescent microscopy. ShHIF- $2 \alpha$ and sh-NC were transfected into T-L-02 cells. At $24 \mathrm{~h}$ after transfection, fluorescent microscopy showed emission green fluorescence. (I) qRT-PCR validated the downregulation of HIF-2 $\alpha$ after shRNA knockdown in T-L-02 cells, ${ }^{*} P<0.05$ different from T-L-02 cells. (J) Colony formation was assessed in soft agar, and representative images of cell migration and cell invasion and (K) their colony numbers and $(\mathbf{L})$ relative migrating/invading cells (means $\pm \mathrm{SD}, n=3$ ) were quantified, bars $=250 \mu \mathrm{m} .{ }^{*} P<0.05$ different from T-L-02 cells. $1 \times 10^{7}$ cells were injected into nude mice $(n=6)$. (M) Tumor volumes were determined $(\mathbf{N})$ at 4 weeks after injection, $(n=6$, mean \pm SD), ${ }^{*} P<0.05$ different from T-L-02 cells. 
of colonies and inhibited the invasion and migration in arsenite-transformed cells (Figure $6 \mathrm{~J}, 6 \mathrm{~K}$ and $6 \mathrm{~L}$ ). The role of HIF-2 $\alpha$ in the malignant and metastatic capacity was confirmed in HCC-LM3 cells, which were also transfected with sh-HIF-2 $\alpha$ (Supplementary Figure S5F, S5G, S5H, S5I and S5J). HIF-2 $\alpha$-knockdown cells were injected into nude mice, HIF- $2 \alpha$ knockdown decreased the tumor sizes relative to the arsenite-treated group (Figure $6 \mathrm{M}$ and $6 \mathrm{~N}$ ). These data indicate that MALAT1 and HIF-2 $\alpha$ are involved in the neoplastic and metastatic capacity of arsenite-transformed L-02 cells.

\section{Arsenite-induced inflammatory response and effects on the levels of HIF-2 $\alpha$ and MALAT1 in mice}

The expressions of MALAT1 and HIF-2 $\alpha$ were evaluated in mice. Four groups of CD1 mice were untreated or treated with low, middle, or high concentrations $(50 \mu \mathrm{M}, 100 \mu \mathrm{M}$, and $200 \mu \mathrm{M}$, respectively) of arsenite, which were added to the drinking water daily for three months. There were no appreciable differences in body weights of the four groups (Supplementary Table 2). However, the expression of MALAT1 in sera and liver tissues of mice exposed to arsenite was increased (Figure $7 \mathrm{~A}$ and 7B, respectively), as were HIF-2 $\alpha$ levels in liver tissues of these mice (Figure 7C and 7D). Our previous study showed that chronic exposure of cultured HBE cells to arsenite induces an inflammatory response associated with HIF-2 $\alpha$, which contributes to arseniteinduced malignant transformation [24]. Although we failed to detect tumors in mice exposed to arsenite, we found that the numbers of macrophages, lymphocytes, and neutrophils in the broncho-alveolar lavage fluid (BALF) of the arsenite-treated group were higher than those for the control group (Figure 7E and Table 3). Further, release of the pro-inflammatory IL-6 cytokine into the BALF and serum increased (Figure 7F, top and bottom, respectively). The mRNA levels and release of other pro-inflammatory cytokines (TNF- $\alpha$ and IL-8) from liver tissue, serum, and BALF increased, but there was no change for IL- $1 \beta$ (Supplementary Figure S6A, S6B, S6C and S6D). These results indicate that arsenite induces inflammation in mice. The expression of IL- 6 positively correlated with the levels of HIF-2 $\alpha$ in liver tissues (Figure 7G). Further, there was a positive correlation between MALAT1 and IL-6 levels (Figure 7H). Thus, arsenite induces overexpression of HIF- $2 \alpha$ and MALAT1 in mice and may cause an elevated inflammatory response.

\section{DISCUSSION}

Inorganic arsenite is a widely distributed, naturally occurring environmental contaminant affecting tens of millions of people worldwide [25]. Chronic exposure to arsenite causes carcinogenesis of lung, skin, liver, and bladder [26]. Various molecular mechanisms have been proposed for arsenite-induced carcinogenesis [27], but the function of lncRNAs in arsenite-induced cancer has not previously been evaluated.

As early as 1976, villagers from Guizhou province in southwestern China were reported to be suffering severe symptoms of arsenicosis, which was attributed to exposure to high levels of arsenic in food, especially in corn and chili peppers, and to a lesser extent by breathing arsenicladen air [28]. miRNAs can be used as biomarkers of disease as well as for arsenic exposure, and can account for disease etiology [29]. Nevertheless, whether or not lncRNAs are involved in arsenite carcinogenesis has remained unknown. The levels of the lncRNA HOTAIR are increased in primary breast tumors and metastases, and its level in primary tumors is a predictor of metastasis and death [15]. MALAT1 is an IncRNA associated with metastasis and survival in early-stage non-small cell lung tumors (NSCLCs) [30]. In some prostate and breast cancer cell lines, expression of GAS5 induces growth arrest and apoptosis independent of other stimuli [31]. After genotoxic stress, lincRNA-p21 is up-regulated in breast cancer cells [32], indicating that it is associated with survival of these cells. Based on their functions, lncRNAs can be classified into oncogene and tumorsuppressor types [33]. In the present study, we collected 32 villagers sera in December 2013, and determined the expression of some common lncRNAs. In those arsenite exposure samples, the arsenite concentrations in urine and hair were higher than those not exposed, and those who were exposed had kidney and liver damage. We also found that, of lncRNAs with elevated expression, MALAT1 had the highest expression. These data indicate that lncRNAs may serve as serum biomarker for diagnosing exposure to arsenite.

lncRNAs are defined as non-coding RNA transcripts longer than $200 \mathrm{nt}$. Thus far, more than 10, 000 lncRNAs have been identified in the human genome [34]. MALAT1 is an lncRNA originally found to be over-expressed in patients at high risk for metastasis of NSCLCs [30]. MALAT1 is up-regulated in human lung cancers, breast cancers, pancreatic cancers, colon cancers, prostate cancers, and endometrial stromal sarcomas [30, 35]. For several cancers, MALAT1 expression is an independent prognostic parameter for survival [18]. Initially, we determined MALAT1 expression in HCC cell lines, HCC tissues, and in paired adjacent normal tissues and found that its expression was higher in HCC cell lines and HCC tissues. We also found that HIF-2 $\alpha$ was over-expressed in 32 paired HCC tissues relative to adjacent normal liver tissues. For HCC patients, high MALAT1 expression was associated with greater tumor size, higher stage, and shorter OS. These results suggest that MALAT1 functions as an oncogene in liver cancer.

Chronic exposure to low levels of arsenite $(<5 \mu \mathrm{M})$ causes cell proliferation, which can lead to neoplastic 
transformation, whereas high levels cause cytotoxicity, indicating that the effects of arsenite are dependent on the degree of exposure $[3,36]$. In the United States and China, the current maximum contaminant level for arsenite in drinking water is $10 \mu \mathrm{g} / \mathrm{L}(\sim 0.5 \mu \mathrm{M})$ [37]. In this study, 1.0 and $2.0 \mu \mathrm{M}$ concentrations of arsenite, lower than levels in drinking water in areas where arsenicosis is common, did not cause cell death [38]. Since the cell proliferation rate induced by $2.0 \mu \mathrm{M}$ arsenite was higher than that induced by $1.0 \mu \mathrm{M}$ arsenite, we used 2.0 $\mu \mathrm{M}$ arsenite for long-term exposures. This low level of arsenite enhanced neoplastic transformation of cells, as determined by anchorage-independent growth in soft agar and tumorigenesis in nude mice. In addition, with increased time of exposure to arsenite, there were more malignant cells and elevated expression of MALAT1. Based on these data, we suggest that MALAT1 may be involved in the neoplastic transformation of L-02 cells induced by arsenite.

Under normoxia, the HIF- $\alpha$ protein is maintained at low levels due to continuous synthesis and degradation, but levels increase rapidly in response to hypoxia [39]. HIF- $\alpha$ is not only induced by hypoxia, but is activated in normoxic cells in response to various stresses [40]. For example, exposure of normoxic cells to peptide mediators, including insulin and IL-1, stabilizes the HIF-1 $\alpha$ protein [41], which is involved in nickel-induced malignant transformation of cells under normoxic conditions [42].
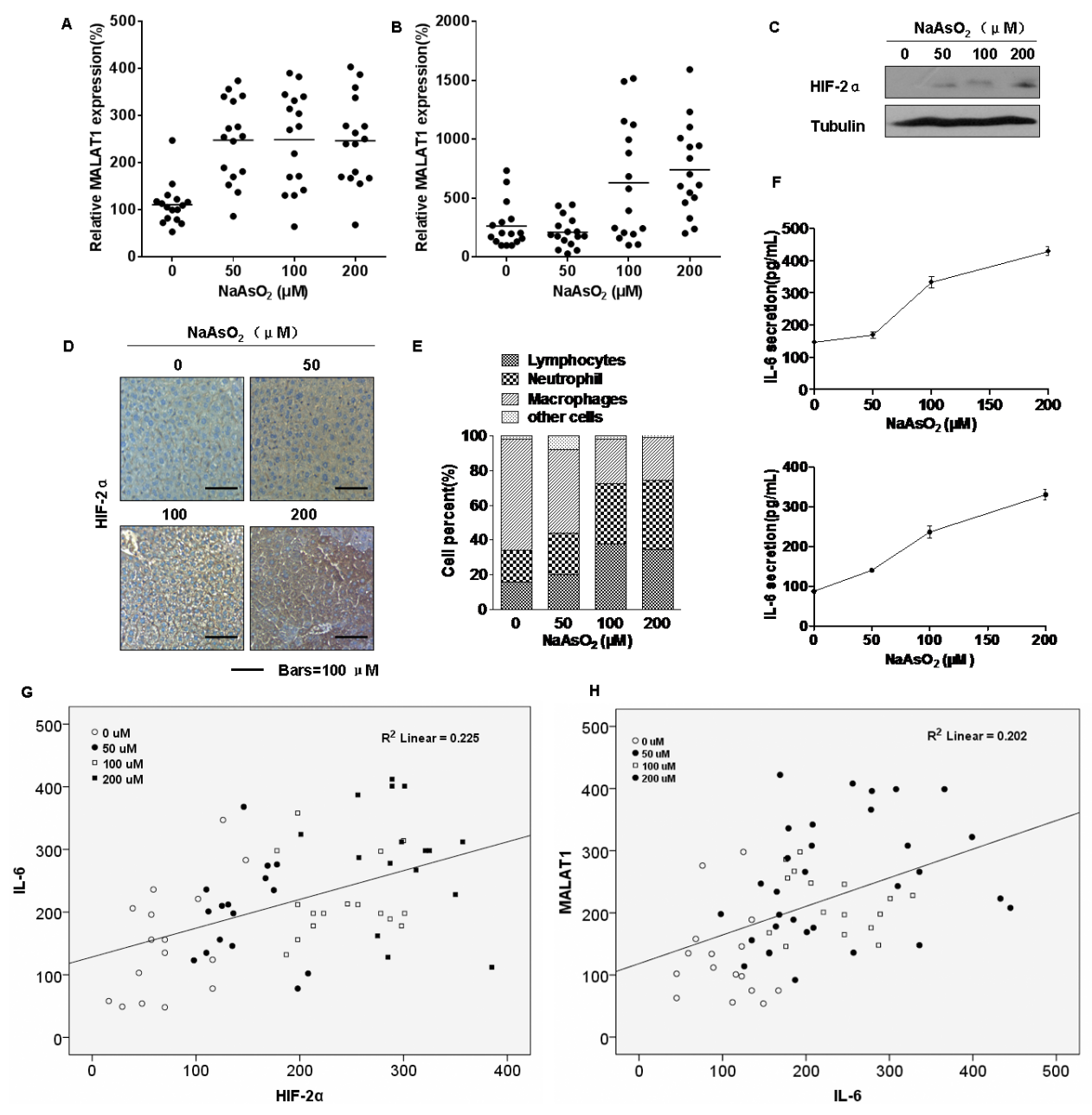

Figure 7: Effect of arsenite on the levels of HIF-2 $\alpha$ and MALAT1 in mice. GAPDH levels, measured in parallel, served as controls. The four groups of CD1 mice were untreated or treated with low, middle, or high concentrations $(50 \mu \mathrm{M}, 100 \mu \mathrm{M}$, or $200 \mu \mathrm{M}$, respectively) of arsenite, which were added to the drinking water daily for 3 months. (A and B) By qRT-PCR assays, the levels of MALAT1 were determined (means $\pm \mathrm{SD}, n=3)$ in sera of animals dosed with arsenite $(n=16)$ and in hepatic tissues of different groups of animals. (C) Western blots for HIF-2 $\alpha$ were made for hepatic tissues of the different groups of animals. (D) Immunohistochemical analyses of HIF- $2 \alpha$ levels in the hepatic tissues of mice treated with low, middle, or high concentrations ( $50 \mu \mathrm{M}, 100 \mu \mathrm{M}$, or $200 \mu \mathrm{M}$, respectively) of arsenite. (E) The BALF cellularity patterns of the groups of CD1 mice untreated or treated with arsenite. (F) The levels of IL-6 present in the mouse mice BALF (top) and serum (bottom) (means $\pm \mathrm{SD}, n=3$ ) were measured by ELISA. (G) The relationship between IL- 6 levels and HIF- $2 \alpha$ levels in the tissues of mice untreated or treated with low, middle, or high concentrations $(50 \mu \mathrm{M}, 100 \mu \mathrm{M}$, and $200 \mu \mathrm{M}$, respectively) of arsenite $\left(n=16, R^{2}=0.225\right)$. (K) The relationship between MALAT1 levels and IL-6 levels in the tissues of mice untreated or treated with low, middle, or high concentrations $\left(50 \mu \mathrm{M}, 100 \mu \mathrm{M}, 200 \mu \mathrm{M}\right.$, respectively) of arsenite $\left(n=16, R^{2}=0.202\right)$. 
Table 3: Effect of arsenite on the recruitment of inflammatory cells into BALF (total inflammatory cells and absolute counts/ml)

\begin{tabular}{|c|c|c|c|c|}
\hline Dose $(\boldsymbol{\mu M})$ & $\begin{array}{c}\text { Total cells } \\
\left(\times \mathbf{1 0}^{3} / \mathbf{m l}\right)\end{array}$ & $\begin{array}{c}\text { Macrophages } \\
\left(\times \mathbf{1 0}^{3} / \mathbf{m l}\right)\end{array}$ & $\begin{array}{c}\text { Lymphocytes } \\
(\times \mathbf{1 0} / \mathbf{m l})\end{array}$ & $\begin{array}{c}\text { Neutrophils } \\
\left(\times \mathbf{1 0}^{3} / \mathbf{m l}\right)\end{array}$ \\
\hline 0 & $25.9 \pm 2.51$ & $16.5 \pm 0.21$ & $4.1 \pm 1.1$ & $4.8 \pm 1.7$ \\
\hline 50 & $40.1 \pm 1.52^{* *}$ & $19.2 \pm 2.14^{* *}$ & $8.1 \pm 1.77^{* *}$ & $9.5 \pm 1.4^{* *}$ \\
\hline 100 & $72.33 \pm 3.7^{* *}$ & $18.5 \pm 3.43^{* *}$ & $27.3 \pm 4.76^{* *}$ & $25.8 \pm 5.1^{* *}$ \\
\hline 200 & $81.2 \pm 4.73^{* *}$ & $19.8 \pm 2.41^{* *}$ & $28.1 \pm 3.1^{* *}$ & $32.3 \pm 4.3^{* *}$ \\
\hline
\end{tabular}

${ }^{* *} P<0.01$, different from control group.

Under normoxic conditions, arsenite and some other metals directly (catalytically) or indirectly induce the stabilization and transactivation of HIF-1 $\alpha$ [5]. The present studies show elevated expression of HIF-2 $\alpha$ in normoxic cells with increased time of exposure to arsenite. Thus, these data indicate that HIF-2 $\alpha$ may be involved in the neoplastic transformation of L-02 cells induced by arsenite.

Although mammalian lncRNAs are best known for modulating transcription, they have a post-transcriptional influence on mRNA splicing, stability, and translation [43]. An example is that HOTAIR facilitates the ubiquitination of ataxin- 1 by Dzip3 and snurportin-1 by mex3b in cells and accelerates their degradation [14]. Moreover, lincRNA-p21 causes disassociation of VHL from HIF-1 $\alpha$, thereby alleviating VHL-mediated HIF-1a ubiquitination and subsequent degradation [13]. Under hypoxic conditions, HIFs accumulate in a posttranslational manner. Under normoxic conditions, the capacity of HIFs to activate transcription is prevented through its hydroxylation. Hydroxylated HIFs recruit the VHL tumor suppressor, leading to the recognition by E3 ubiquitin ligase and subsequent ubiquitination and proteasome-dependent degradation [44]. The arseniteinduced accumulation of HIF apparently relates to posttranscriptional regulation [5].

Since, in the present research, both MALAT1 and HIF- $2 \alpha$ were induced by arsenite in L- 02 cells, we speculated that MALAT1 regulates HIF- $2 \alpha$ degradation through the ubiquitin-proteasome pathway. Consistent with this hypothesis, HIF- $2 \alpha$ mRNA levels were not affected by knockdown of MALAT1, but there was a decrease of HIF- $2 \alpha$ protein in L-02 cells exposed to arsenite, moreover, mRNA levels of HIF- $2 \alpha$ target genes, VEGF and Oct4, were decreased. The HIF- $2 \alpha$ reduction caused by MALAT1 knockdown was rescued by the proteasome inhibitor MG132. Moreover, reduced degradation of hyp 531 HIF- $2 \alpha$ enhanced the HIF- $2 \alpha$-VHL interaction and increased HIF-2 $\alpha$ polyubiqutination. Thus, arsenite-induced MALAT1 causes disassociation of VHL from HIF- $2 \alpha$ and thereby alleviates VHL-mediated HIF- $2 \alpha$ ubiquitination and subsequent degradation.

Similar to human lincRNA-p21, which is induced by hypoxia, other lncRNAs, including H19 and lncRNA-low expression in tumor (LET), are regulated by hypoxia and are involved in hypoxia-induced signaling transduction in cancer $[45,46]$. These observations, together with ours, suggest that lncRNAs are involved in the regulation of hypoxia-induced signaling induced by arsenite. HIFs transcriptionally regulate expression of a variety of genes by binding to HREs in their promoters [47]. In the present study, analysis of the gene promoter region (MatInspector) allowed us to predict that there are three putative HREs $\left(5^{\prime}-R C G T G-3^{\prime}\right)$ in gene promoter region of the MALAT1 gene, suggesting that HIF- $2 \alpha$ regulates MALAT1 expression via binding to HREs. We determined the association of HIF- $2 \alpha$ and the chromatin fragments corresponding to the third HRE within the MALAT1 gene in L-02 cells exposed to arsenite and in HCC-LM3 cells. Further, inhibition of HIF-2 $\alpha$ decreased expression of MALAT1, and HIF-2 $\alpha$ upregulated MALAT1-HRE3 transcriptional activity. These results indicate that MALAT1 is transcriptionally up-regulated by HIF- $2 \alpha$ in L-02 cells exposed to arsenite.

MALAT1 was originally identified as an lncRNA, showing high expression in individuals at high risk for metastasis of non-small cell lung tumors [6]. Its expression is upregulated in a range of tumors, including lung cancer, liver cancer, renal cell carcinoma, bladder cancer, and osteosarcoma [48]. HIF-2 $\alpha$ is involved in tumor cell proliferation, apoptosis, migration, and invasion and in the metastatic spread of tumor cells [47]. Our studies focused on the effects of MALAT1 and HIF-2 $\alpha$ on the neoplastic and invasive capacity of cells after long-term exposure to arsenite. Knockdown of MALAT1 with lentivirus shRNA inhibited the neoplastic and invasive capacity of arsenitetransformed L-02 cells and HCC-LM3 cells. The roles of HIF- $2 \alpha$ in solid tumors have been assessed [47]. We also found that knockdown of HIF-2 $\alpha$ with lentivirus shRNA inhibited the neoplastic and invasive capacity of arsenitetransformed L-02 cells and HCC-LM3 cells. These results indicate that MALAT1 and HIF- $2 \alpha$ are involved in the neoplastic and metastatic capacity of arsenite-transformed L-02 cells and HCC-LM3 cells.

Finally, we determined that MALAT1 and HIF- $2 \alpha$ were up-regulated in mice exposed to arsenite for three months. MALAT1 was over-expressed in mouse serum and liver tissues, and HIF-2 $\alpha$ levels were elevated in liver 
tissues of these mice. Low-dose arsenic exposures (5-250 $\mathrm{ppb}$ in drinking water, or $\mathrm{nM}$ to low $\mu \mathrm{M}$ concentrations) increased neovascularization of chicken chorioallantoic membranes, stimulated inflammatory angiogenesis in a mouse Matrigel assay, and increased vascular density and vessel size in mouse tumors [49]. Our previous study showed that chronic arsenite exposure of cultured HBE cells induces an inflammatory response, which contributes to arsenite-induced malignant transformation [24]. We have shown that arsenite induces inflammation in mice, but does not cause tumors. Michael P. Waalkes research team confirmed that lung, liver, gallbladder, and ovarian tumors could be induced by "whole-life" inorganic arsenic exposure in CD1 mice at human-relevant doses [50, 51]. Although short time exposure to arsenic did not induce tumors, our results could provide a hint that MALAT1 and HIF-2 $\alpha$ over-expression were involved in arsenite carcinogenesis. In the future, we plan to implement whole-life exposure of mice to arsenite and determine the relationship between arsenite carcinogenesis and HIF- $2 \alpha$ and MALAT1. In addition, the expression of IL- 6 positively correlated with the levels of HIF-2 $\alpha$ in liver tissues of mice. Further, there was a positive correlation between MALAT1 and IL- 6 in liver tissues of mice. These data indicate that arsenite induces HIF- $2 \alpha$ and MALAT1 over-expression in animals and induces an inflammatory response.

In summary, we have shown that MALAT1, a noncoding RNA, was over-expressed in the sera of people exposed to arsenite and in hepatocellular carcinomas (HCCs), and MALAT1 had a close relation with the clinicopathological characteristics of HCC. In addition, hypoxia-inducible factor (HIF)-2 $\alpha$ was up-regulated in HCCs, and MALAT1 and HIF-2 $\alpha$ had a positive correlation in HCC tissues. In addition, in arsenite-induced neoplastic transformation of L-02 cells, over-expression of MALAT1 increased HIF-2 $\alpha$ expression through the ubiquitin-proteasome pathway. In turn, HIF- $2 \alpha$ transcriptionally regulated MALAT1, thus forming a positive feedback loop to ensure arsenite-induced MALAT1 and HIF-2 $\alpha$ expression, which were involved in malignant transformation and carcinogenesis. We also found that, in mice, arsenite induced an inflammatory response and over-expression of MALAT1 and HIF- $2 \alpha$. Together, these findings suggest that the MALAT1/ HIF-2 $\alpha$ feedback loop was involved in regulation of arsenite-induced malignant transformation. Our results not only confirm a novel mechanism involving reciprocal regulation of MALAT1 and HIF- $2 \alpha$ and also expand the understanding of the carcinogenic potential of arsenite.

\section{MATERIALS AND METHODS}

\section{Biological samples}

We consulted a database maintained by the Guizhou Provincial Office of Endemic Disease to identify populations exposed to arsenite [52]. In December 2013, our team collected samples from the target population, with a total of 32 villagers agreeing to participate in the study. Their participation was approved by our institutional review board. Informed consent could not be offered, because the data were analyzed anonymously. Arsenicosis symptoms were categorized based on the degree of symptoms: nonpatient $(n=16)$ and severe patient $(n=16)$. Symptoms were classified according to the Chinese National Arsenicosis Diagnosis Standard protocol [52]. Patients $(n=16)$, defined as individuals showing symptoms of arsenicosis, from Jiaole, Guizhou province, were designated the arsenite exposure group. The other 16 villagers, from near Jiaole who were not exposed to arsenite and had no symptoms of arsenicosis, were as designated the control group (Table 1).

\section{Patients and tissue samples}

A total of 32 Chinese $\mathrm{HCC}$ patients were involved. Consent was obtained for all patients. These patients underwent curative liver resection for primary tumors between March 2009 and July 2012 in the Department of General Surgery, The Second Affiliated Hospital, Nanjing Medical University. The inclusion criteria for the patient cohort included (i) having a distinctive pathological diagnosis of HCC; (ii) surgical resection, defined as complete resection of all tumor nodules with the cut margin being free of cancer by histological examination; and (iii) having complete clinicopathological data. An exclusion criterion was having anticancer treatment before liver resection. None of the patients had extrahepatic metastases when they underwent hepatectomy. The clinicopathological characteristics of the patients are listed in Table 2. This study was reviewed and approved by Medical Ethics Committee of the Second Affiliated Hospital of Nanjing Medical University.

\section{Animals}

Mice (CD1) were purchased from Shanghai Laboratory Animal Center, Shanghai, China), and housed in the animal facilities at the Jiangsu Center for Disease Control and Prevention. Animals were treated humanely and with regard for alleviation of suffering according to a protocol approved by the Jiangsu Center for Disease Control and Prevention Institutional Animal Care and Use Committee. Briefly, 64 male CD1 mice aged 7-8 weeks were randomly divided into four groups (16 mice per group). One group was reserved as the non-treated control group. The other three groups were treated with low, middle, and high concentrations of arsenite $(50 \mu \mathrm{M}$, $100 \mu \mathrm{M}$, and $200 \mu \mathrm{M}$, respectively), which was added to the drinking water daily for three months. 


\section{Cell culture and reagents}

L-02 cells, a normal human liver cell line, and HCC cell lines (HepG2, SMMC-7721, Bel-7402, MHCC97H, and HCC-LM3) were obtained from the Shanghai Institute of Cell Biology, Chinese Academy of Sciences (Shanghai, China) and were maintained in $5 \% \mathrm{CO}_{2}$ at $37^{\circ} \mathrm{C}$ in RPMI1640 or DMEM medium, respectively, supplemented with $10 \%$ fetal bovine serum (FBS, Life Technologies/Gibco, Grand Island, NY), $100 \mathrm{U} / \mathrm{ml}$ penicillin, and $100 \mu \mathrm{g} / \mathrm{ml}$ streptomycin (Life Technologies/Gibco, Gaithersburg, MD). For chronic exposure, $1 \times 10^{6} \mathrm{~L}-02$ cells were seeded into 10-cm (diameter) dishes for $24 \mathrm{~h}$ and maintained in 0.0 or $2.0 \mu \mathrm{M}$ sodium arsenite $\left(\mathrm{NaAsO}_{2}\right.$, Sigma, St. Louis, MO; purity, $99.0 \%$ ) for $48-72 \mathrm{~h}$ per passage. This process was continued for about 15 weeks (30 passages); desferroxamine (DFX), an iron chelator routinely used to mimic hypoxia, was purchased from Sigma. The proteasome inhibitor, MG132, and the protein synthesis inhibitor, cycloheximide (CHX), were purchased from Calbiochem (Darmstadt, Germany). All other reagents were of analytical grade or the highest grade available.

\section{Serum RNA extraction}

Blood samples were centrifuged at $15000 \mathrm{~g}$ to separate the sera. All of the samples were collected and stored at $-70^{\circ} \mathrm{C}$ and thawed immediately before assay. Total RNA was isolated from serum using TRIzol LS reagent (Invitrogen, Life Technologies, Paisley, UK) according to manufacturer's instructions with the following modifications: In brief, each $250 \mu \mathrm{l}$ serum sample was mixed with $750 \mu \mathrm{l}$ TRIzol LS Reagent. After $5 \mathrm{~min}$ incubation at room temperature, $200 \mu \mathrm{l}$ of chloroform was added, followed by $15 \mathrm{sec}$ of shaking and $10 \mathrm{~min}$ of incubation at room temperature. The mixture was centrifuged at $12,000 \mathrm{~g}$ for $15 \mathrm{~min}$ at $4^{\circ} \mathrm{C}$ in a concentrator (Eppendorf-Netheler-Hinz, Hamburg, Germany). The aqueous layer containing RNA was transferred into a new tube, then RNA was precipitated for $16 \mathrm{hr}$ at $-20^{\circ} \mathrm{C}$ with $0.5 \mathrm{ml}$ isopropyl alcohol and washed with $1 \mathrm{ml}$ of $75 \%$ ethanol. Finally, the RNA pellet was dried for $5-10 \mathrm{~min}$ at room temperature, dissolved at $60^{\circ} \mathrm{C}$ in $15 \mu \mathrm{l}$ of RNase-free water. The RNA concentration was measured with a NanoDrop spectrophotometer (Thermo Fisher Scientific). The final concentrations of RNA ranged from $319 \sim 782 \mathrm{ng} / \mu \mathrm{l}$. The TRIzol method is described in other studies [53, 54].

\section{Reverse-transcriptase polymerase chain reaction (RT-PCR)}

Total cellular and tissue RNA was isolated by use of TRIzol (Invitrogen) according to the manufacturer's recommendations. Total RNA $(2 \mu \mathrm{g})$ was transcribed into cDNA by the use of AMV reverse transcriptase (Promega,
Madison, Wisconsin, USA). Primers used are listed in Supplementary Table 1. PCR was evaluated by checking the products on $2 \% \mathrm{w} / \mathrm{v}$ agarose gels. Bands were quantified by densitometry and normalized by the use of glyceraldehyde 3-phosphate dehydrogenase (GAPDH) or 18s ribosomal RNA to correct for differences in loading. For densitometric analyses, the mRNA bands on the gels were measured by Eagle Eye II.

\section{Quantitative real-time PCR (qRT-PCR)}

The levels of lncRNAs were determined by qRTPCR. 18s ribosomal RNA was used as a control. Forward (F) and reverse (R) primers were as follows: MALAT1-F, 5'-ACTACCAGCCATTTCTCC -3'; MALATI-R, 5'-ACC ACCACAGGTTTACAG -3'; 18s-F, 5'-GTAACCCGTTGAA CCCCATT -3'; 18s-R, 5'-CCATCCAATCGGTAGTAGCG -3'. GAS5-F, 5'-CAATAGATTCCTTCGCTCC-3'; GAS5-R, 5'-AGTTCACCTCTGGGTTTCA-3'. LincRNA-p21-F, 5'-AT TGCTCGTTCTTCTTATC-3'; LincRNA-p21-R, 5'-CCCTG GACCTCATTACTT-3'. H19-F, 5'-TCCAGAAAGAGGGA GTTG-3'; H19-R, 5'-GAAGCCAGACCCAGTAAG -3'. HOTAIR-F, 5'-ACCCACCAGATAAGATACAAAT-3'; and HOTAIR-R, 5'-CACAGCATCAATACCTCCCT-3'. All of the primers were synthesized by Invitrogen. qRT-PCR was performed with an Applied Biosystems 7300HT machine and MaximaTM SYBR Green/ROX qPCR Master Mix (Fermentas). Fold changes in expression of each gene were calculated by a comparative threshold cycle $(\mathrm{Ct})$ method using the formula $2^{-(\Delta \Delta \mathrm{Ct})}$. And the absolute expression in each subject was calculated with a standard curve, and the mean value of the control group was determined. The relative values between each sample and the mean values were calculated.

\section{Western blots}

Total cell lysates were prepared with a detergent buffer, as described [55]. Protein concentrations were measured with the BCA Protein Assay according to the manufacturer's manual (Beyotime Institute of Biotechnology, Shanghai, China). Equal amounts $(80 \mu \mathrm{g})$ of protein were separated by $10 \%$ sodium dodecyl sulfatepolyacrylamide gel electrophoresis and were transferred to polyvinylidene fluoride membranes (Millipore, Billerica, MA). Membranes were incubated overnight at $4^{\circ} \mathrm{C}$ with a 1:1000 dilution of anti-GAPDH (Sigma) and antibodies for HIF-2 $\alpha$ (Abcam), VHL protein (Cell Signaling Technology, Beverly, MA), and ubiquitin (Novus, Littleton, CO). After additional incubation with a 1:1000 dilution of an anti-immunoglobin horseradish peroxidaselinked antibody for $1 \mathrm{~h}$, the immune complexes were detected by enhanced chemiluminescence (Cell Signaling Technology). For densitometric analyses, protein bands on the blots were measured by the use of Eagle Eye II software. 


\section{Determination of cell proliferation}

Cell proliferation was evaluated by WST- 8 (a tetrazolium salt that is cleaved to formazan) hydrolysis using cell counting kit-8 (Dojindo Molecular Technologies, Inc.), as described previously [56]. Briefly, cells were seeded into 96-well tissue culture plates at 4000 cells per well. Plates were incubated for $24 \mathrm{~h}$ at $37^{\circ} \mathrm{C}$ with $5 \% \mathrm{CO}_{2}$ in a humidified incubator. After the cells were treated and incubated, $20 \mu \mathrm{L}$ of WST- 8 was added to each well, and the incubation was continued for an additional $3 \mathrm{~h}$. Samples from at least three independent experiments were analyzed in duplicate. The relative cell proliferation ratios were plotted with non-treated controls to determine the $100 \%$ activity level.

\section{Growth kinetics}

Control and arsenite-treated L-02 cells were seeded in 6-well plates at a concentration of $1 \times 10^{5}$ per well. The plates were incubated at $37^{\circ} \mathrm{C}$ under $5 \% \mathrm{CO}_{2}$ in RPMI1640 medium supplemented with $10 \%$ FBS for 24,48 , or $72 \mathrm{~h}$, then collected by trypsinization. Cells were counted in triplicate using a hemocytometer under a microscope. The population doubling time was obtained by the formula: TD $=T \times \log 2 /\left(\log N_{\mathrm{t}}-\log N_{0}\right)$, where $N_{\mathrm{t}}$ is the inoculum cell number, $N_{0}$ is the cell harvest number, and $\mathrm{t}$ is the time of the culture (in h) [4].

\section{RNA interference}

Transfections of L-02 cells were performed with the N-TER ${ }^{\mathrm{TM}}$ and AccuTarget TMN nanoparticle siRNA Transfection System (Sigma, BIONEER) following the manufacturer's protocol. Briefly, $5 \times 10^{5}$ cells were seeded into each well of 6 -well plates, $18-24 \mathrm{~h}$ prior to transfection. The siRNA nanoparticle preparations were made by adding target gene siRNA dilutions to N-TER or AccuTarget peptide dilutions. Control siRNA and HIF- $2 \alpha$ siRNA were purchased from Santa Cruz Biotechnology (Santa Cruz, CA). Control siRNA and MALAT1 siRNA were purchased from BIONEER.

\section{Cell transfection}

The plasmid of HIF- $2 \alpha$ was a gift from Dr. Rui Chen (Department of Internal Medicine, University of Texas Southwestern Medical Center at Dallas, USA). Cells were transiently transfected by use of the Lipofectamine 2000 reagent (Invitrogen, Carlsbad, CA, USA) according to the manufacturer's protocol. At $24 \mathrm{~h}$ after transfection, cells were treated, harvested, and used for experiments.

\section{ELISA assays}

To determine the amounts of inflammatory cytokines in CD1 mouse serum and bronchoalveolar lavage fluid
(BALF), ELISA tests were performed according to the manufacturer's instructions. A human-specific interleukin (IL)-6, IL-8, IL-1 $\beta$ and TNF- $\alpha$ ELISA from Beijing 4A Biotech Co., Ltd (Beijing) was used to determine the amounts of inflammatory cytokines. All assays were performed in duplicate and repeated three times.

\section{Anchorage-independent growth}

Soft-agar dishes were prepared with under-layers of $0.70 \%$ agarose in RPMI- 1640 or DMEM medium supplemented with $10 \%$ FBS. To test their capacity for soft-agar growth, cells were plated in triplicate at a density of $1 \times 10^{4}$ in $2 \mathrm{ml}$ of $0.35 \%$ agarose. Cultures were fed every 3 days. After 14 days, the colonies were observed under a microscope, and colonies with diameters $>80 \mu \mathrm{m}$ were counted. These represent colonies with $>30$ cells.

\section{Co-immunoprecipitation}

Cells were extracted for 30 min with lysis buffer. After centrifugation of the preparations, the supernatants were incubated with HIF-2 $\alpha$ antibody and subsequently with $\mathrm{A}+\mathrm{G}$ Sepharose beads (Sigma) at $4^{\circ} \mathrm{C}$ overnight. The pellets were washed three times, re-suspended in SDS sample buffer, and boiled to remove protein from the beads. The immunoprecipitates were analyzed by Western blots with anti-ubiquitin, HIF-2 $\alpha$, and VHL antibodies.

\section{Chromatin immunoprecipitation (ChIP)}

ChIP was performed as previously described [57]. Cells $\left(1 \times 10^{7}\right)$ were cross-linked in $1 \%$ formaldehyde for $10 \mathrm{~min}$. After cell lysis, the chromatin was fragmented to an average size of $500 \mathrm{bp}$ and enriched with a magnetic Dynal bead (Invitrogen)-coupled antibody against HIF- $2 \alpha$ or with isotype $\operatorname{IgG}$ at $4^{\circ} \mathrm{C}$ overnight. The cross-links for the enriched and the input DNA were then reversed, and the DNA was cleaned by RNase A $(0.2 \mathrm{mg} / \mathrm{mL})$ and proteinase $\mathrm{K}(2 \mathrm{mg} / \mathrm{mL})$ before phenol/ chloroform purification. The specific sequences from immunoprecipitated and input DNA were determined by PCR primers for MALAT1 promoter upstream regions: MALAT1 promoter (containing HRE1) forward, 5'-TGA GGCTGGAGTGCAGTGGC - 3', and reverse, 5'-AGGGA GGCGGAGGTTACGGT - $-3^{\prime}$, the amplicon size was $55 \mathrm{bp}$; MALAT1 promoter (containing HRE2) forward, 5'-GGAG ATTTTGTGATTTGC - $3^{\prime}$, and reverse, 5'-TGACAGAA GTGCTGGAGA -3', the amplicon size was $114 \mathrm{bp}$; MA LAT1 promoter (containing HRE3) forward, 5'-CCCTAA CGCCTGTGCCTGTT-3', and reverse, 5'-CGCAGAG TAGCGACCGAGAA-3'; the amplicon size was $83 \mathrm{bp}$.

\section{Transwell assays}

Migratory and invasive capacities of arsenitetreated L-02 cells and HCC-LM3 cells were evaluated 
using Transwell chambers without or with Matrigel, respectively.

\section{Luciferase activity assay}

The pGL3-MALAT1-P1-Luc construct, the pGL3MALAT1-P2-Luc construct, and the mut-Luc construct were purchased from Genechem (Shanghai, China). The plasmid phRL-tk (used as internal control for transfection efficiency and cytotoxicity of test chemicals) containing the Renilla luciferase gene was purchased from Promega (Madison, WI, USA). The cells proliferated to $60-80 \%$ confluence after $24 \mathrm{~h}$ of culture. Then, the cells were co-transfected with $2 \mu \mathrm{g}$ of DNA of the reporter constructs and HIF- $2 \alpha$ plasmid or HIF- $2 \alpha$ siRNA using the Lipofectamine 2000 reagent (Invitrogen, Carlsbad, CA) according to the manufacturer's protocol. The amounts of luciferase and Renilla luciferase were measured with the Dual-Luciferase Reporter Assay System Kit (Promega) following the manufacturer's instructions. The values of luciferase activity for each lysate were normalized to the Renilla luciferase activity. The relative transcriptional activity was converted into fold induction above the vehicle control value.

\section{Lentiviral vector transfection}

For knockdown of MALAT1 or HIF-2 $\alpha$ expression, lentivirus particles carrying shRNA specifically targeting MALAT1 or HIF-2 $\alpha$ were purchased from GeneChem (Shanghai, China). For cell infection, 60\% confluent arsenite-transformed L-02 cells or HCC-LM3 cells were incubated with 50 or $30 \mathrm{MOI}$ of lentivirus, respectively, and $5 \mu \mathrm{g} / \mathrm{ml}$ of polybrene. After $24 \mathrm{~h}$ of transfection, the transfection medium was replaced with medium containing puromycin ( $5 \mu \mathrm{g} / \mathrm{ml}$; Sigma-Aldrich) for at least 2 weeks before usage to select stable cell pools. Successful transduction was determined by counting the green fluorescence emitted from GFP-stained lentiviral particles under a fluorescence microscope (EVOS FL, Advanced Microscopy Group, Mill Creek, Washington). Cells infected with lentivirus with empty vector (sh-NC) were used as controls.

\section{Immunohistochemistry}

Immunohistochemical staining was performed on formalin-fixed, paraffin-embedded tumor samples. Sections mounted on silanized slides were de-waxed in xylene, dehydrated in ethanol, boiled in $0.01 \mathrm{M}$ citrate buffer (pH 6.0) for $20 \mathrm{~min}$ in a microwave oven, and then incubated with $3 \%$ hydrogen peroxide for $5 \mathrm{~min}$. After washing with PBS, sections were incubated in $10 \%$ normal bovine serum albumin for $5 \mathrm{~min}$, followed by overnight incubation with a rabbit anti-human HIF-2 $\alpha$ antibody and with an anti-rabbit horseradish peroxidase-conjugated secondary antibody at room temperature for $30 \mathrm{~min}$. The sections were then counterstained with hematoxylin, dehydrated, cleared, and mounted.

\section{Statistical analyses}

Derived values are presented as the means $\pm \mathrm{SD}$. Comparison of mean data among multiple groups was analyzed by one-way analysis of variance (ANOVA), and a multiple range least significant difference (LSD) was used for inter-group comparisons. $P$ values $<0.05$ were considered statistically significant. All statistical analyses were performed with SPSS 16.0.

\section{ACKNOWLEDGMENTS}

The authors wish to thank Donald L. Hill (University of Alabama at Birmingham, USA), an experienced, English-speaking scientific editor for editing.

\section{FUNDINGS}

This work was supported by the Natural Science Foundations of China (81273114, 81430077, 81302467), the Postgraduate Innovation Project of Jiangsu province (CXZZ14 0421, CXZZ14_0951, and KYLX15_0974), and the Priority Academic Program Development of Jiangsu Higher Education Institutions (2010).

\section{CONFLICTS OF INTEREST}

The authors declare they have no competing financial interests.

\section{REFERENCES}

1. Hong YS, Song KH, Chung JY. Health effects of chronic arsenic exposure. Journal of preventive medicine and public health. 2014; 47:245-252.

2. Pi J, Diwan BA, Sun Y, Liu J, Qu W, He Y, Styblo M, Waalkes MP. Arsenic-induced malignant transformation of human keratinocytes: involvement of Nrf2. Free radical biology \& medicine. 2008; 45:651-658.

3. Wen G, Calaf GM, Partridge MA, Echiburu-Chau C, Zhao Y, Huang S, Chai Y, Li B, Hu B, Hei TK. Neoplastic transformation of human small airway epithelial cells induced by arsenic. Mol Med. 2008; 14:2-10.

4. Xu Y, Li Y, Pang Y, Ling M, Shen L, Jiang R, Zhao Y, Zhou J, Wang X, Liu Q. Blockade of p53 by HIF-2alpha, but not HIF-1alpha, is involved in arsenite-induced malignant transformation of human bronchial epithelial cells. Archives of toxicology. 2012; 86:947-959.

5. Guo W, Yang Z, Xia Q, Liu J, Yu Y, Li J, Zuo Z, Zhang D, Li X, Shi X, Huang C. Arsenite stabilizes HIF-1alpha protein through p85alpha-mediated up-regulation of 
inducible Hsp70 protein expression. Cellular and molecular life sciences. 2011; 68:475-488.

6. Harris AL. Hypoxia-a key regulatory factor in tumour growth. Nature reviews Cancer. 2002; 2:38-47.

7. Ortiz-Barahona A, Villar D, Pescador N, Amigo J, del Peso L. Genome-wide identification of hypoxia-inducible factor binding sites and target genes by a probabilistic model integrating transcription-profiling data and in silico binding site prediction. Nucleic acids research. 2010; 38:2332-2345.

8. Choudhry H, Schodel J, Oikonomopoulos S, Camps C, Grampp S, Harris AL, Ratcliffe PJ, Ragoussis J, Mole DR. Extensive regulation of the non-coding transcriptome by hypoxia: role of HIF in releasing paused RNApol2. EMBO reports. $2014 ; 15: 70-76$.

9. Camps C, Saini HK, Mole DR, Choudhry H, Reczko M, Guerra-Assuncao JA, Tian YM, Buffa FM, Harris AL, Hatzigeorgiou AG, Enright AJ, Ragoussis J. Integrated analysis of microRNA and mRNA expression and association with HIF binding reveals the complexity of microRNA expression regulation under hypoxia. Molecular cancer. 2014; 13:28.

10. Gutschner T, Diederichs S. The hallmarks of cancer: a long non-coding RNA point of view. RNA biology. 2012; 9:703-719.

11. Rinn JL, Chang HY. Genome regulation by long noncoding RNAs. Annual review of biochemistry. 2012; 81:145-166.

12. Yoon JH, Abdelmohsen K, Srikantan S, Yang X, Martindale JL, De S, Huarte M, Zhan M, Becker KG, Gorospe M. LincRNA-p21 suppresses target mRNA translation. Molecular cell. 2012; 47:648-655.

13. Yang F, Zhang H, Mei Y, Wu M. Reciprocal regulation of HIF-1alpha and lincRNA-p21 modulates the Warburg effect. Molecular cell. 2014; 53:88-100.

14. Yoon JH, Abdelmohsen K, Kim J, Yang X, Martindale JL, Tominaga-Yamanaka K, White EJ, Orjalo AV, Rinn JL, Kreft SG, Wilson GM, Gorospe M. Scaffold function of long non-coding RNA HOTAIR in protein ubiquitination. Nature communications. 2013; 4:2939.

15. Woo CJ, Kingston RE. HOTAIR lifts noncoding RNAs to new levels. Cell. 2007; 129:1257-1259.

16. Wapinski O, Chang HY. Long noncoding RNAs and human disease. Trends in cell biology. 2011; 21:354-361.

17. Yu W, Qiao Y, Tang X, Ma L, Wang Y, Zhang X, Weng W, Pan Q, Yu Y, Sun F, Wang J. Tumor suppressor long non-coding RNA, MT1DP is negatively regulated by YAP and Runx 2 to inhibit FoxA1 in liver cancer cells. Cellular signalling. 2014; 26:2961-2968.

18. Shi X, Sun M, Liu H, Yao Y, Song Y. Long non-coding RNAs: a new frontier in the study of human diseases. Cancer letters. 2013; 339:159-166.

19. Zhang L, Huang G, Li X, Zhang Y, Jiang Y, Shen J, Liu J, Wang Q, Zhu J, Feng X, Dong J, Qian C. Hypoxia induces epithelial-mesenchymal transition via activation of SNAI1 by hypoxia-inducible factor -1alpha in hepatocellular carcinoma. BMC cancer. 2013; 13:108.

20. Bangoura G, Yang LY, Huang GW, Wang W. Expression of HIF-2alpha/EPAS1 in hepatocellular carcinoma. World journal of gastroenterology. 2004; 10:525-530.

21. Lopez-Barneo J, del Toro R, Levitsky KL, Chiara MD, Ortega-Saenz P. Regulation of oxygen sensing by ion channels. J Appl Physiol. 2004; 96:1187-1195; discussion 1170-1182.

22. Toledo RA, Qin Y, Srikantan S, Morales NP, Li Q, Deng Y, Kim SW, Pereira MA, Toledo SP, Su X, Aguiar RC, Dahia PL. In vivo and in vitro oncogenic effects of HIF2A mutations in pheochromocytomas and paragangliomas. Endocrine-related cancer. 2013; 20:349-359.

23. Michalik KM, You X, Manavski Y, Doddaballapur A, Zornig M, Braun T, John D, Ponomareva Y, Chen W, Uchida S, Boon RA, Dimmeler S. Long noncoding RNA MALAT1 regulates endothelial cell function and vessel growth. Circulation research. 2014; 114:1389-1397.

24. Xu Y, Zhao Y, Xu W, Luo F, Wang B, Li Y, Pang Y, Liu Q. Involvement of HIF-2alpha-mediated inflammation in arsenite-induced transformation of human bronchial epithelial cells. Toxicology and applied pharmacology. 2013; 272:542-550.

25. IARC Working Group on the Evaluation of Carcinogenic Risks to Humans. Some drinking-water disinfectants and contaminants, including arsenic. Monographs on chloramine, chloral and chloral hydrate, dichloroacetic acid, trichloroacetic acid and 3-chloro-4-(dichloromethyl)-5-hydroxy-2(5H)furanone. IARC monographs on the evaluation of carcinogenic risks to humans. 2004; 84:269-477.

26. Li L, Lu Y, Stemmer PM, Chen F. Filamin A phosphorylation by Akt promotes cell migration in response to arsenic. Oncotarget. 2015; 6:12009-12019. doi: 10.18632/oncotarget.3617.

27. Stueckle TA, Lu Y, Davis ME, Wang L, Jiang BH, Holaskova I, Schafer R, Barnett JB, Rojanasakul Y. Chronic occupational exposure to arsenic induces carcinogenic gene signaling networks and neoplastic transformation in human lung epithelial cells. Toxicology and applied pharmacology. 2012; 261:204-216.

28. Zhou DX. Investigation of chronic arsenic poisoning caused by high arsenic coal pollution. [Article in Chinese] Zhonghua Yu Fang Yi Xue Za Zhi. 1993; 27:147-150.

29. Sharma D, Tiwari M, Lakhwani D, Tripathi RD, Trivedi PK. Differential expression of microRNAs by arsenate and arsenite stress in natural accessions of rice. Metallomics. 2015; 7:174-187.

30. Ji P, Diederichs S, Wang W, Boing S, Metzger R, Schneider PM, Tidow N, Brandt B, Buerger H, Bulk E, Thomas M, Berdel WE, Serve H, Muller-Tidow C. MALAT-1, a novel noncoding RNA, and thymosin beta4 predict metastasis and survival in early-stage non-small cell lung cancer. Oncogene. 2003; 22:8031-8041. 
31. Mourtada-Maarabouni M, Pickard MR, Hedge VL, Farzaneh F, Williams GT. GAS5, a non-protein-coding RNA, controls apoptosis and is downregulated in breast cancer. Oncogene. 2009; 28:195-208.

32. Ozgur E, Mert U, Isin M, Okutan M, Dalay N, Gezer U. Differential expression of long non-coding RNAs during genotoxic stress-induced apoptosis in HeLa and MCF-7 cells. Clinical and experimental medicine. 2013; 13:119-126.

33. Guttman M, Donaghey J, Carey BW, Garber M, Grenier JK, Munson G, Young G, Lucas AB, Ach R, Bruhn L, Yang X, Amit I, Meissner A, et al. lincRNAs act in the circuitry controlling pluripotency and differentiation. Nature. 2011; 477:295-300.

34. Han BW, Chen YQ. Potential pathological and functional links between long noncoding RNAs and hematopoiesis. Science signaling. 2013; 6:re5.

35. Yamada K, Kano J, Tsunoda H, Yoshikawa H, Okubo C, Ishiyama T, Noguchi M. Phenotypic characterization of endometrial stromal sarcoma of the uterus. Cancer science. 2006; 97:106-112.

36. Shen S, Lee J, Weinfeld M, Le XC. Attenuation of DNA damage-induced p53 expression by arsenic: a possible mechanism for arsenic co-carcinogenesis. Molecular carcinogenesis. 2008; 47:508-518.

37. Huang Y, Zhang J, McHenry KT, Kim MM, Zeng W, Lopez-Pajares V, Dibble CC, Mizgerd JP, Yuan ZM. Induction of cytoplasmic accumulation of p53: a mechanism for low levels of arsenic exposure to predispose cells for malignant transformation. Cancer research. 2008; 68:9131-9136.

38. Pi J, Yamauchi H, Kumagai Y, Sun G, Yoshida T, Aikawa H, Hopenhayn-Rich C, Shimojo N. Evidence for induction of oxidative stress caused by chronic exposure of Chinese residents to arsenic contained in drinking water. Environmental health perspectives. 2002; 110:331-336.

39. Hu CJ, Sataur A, Wang L, Chen H, Simon MC. The $\mathrm{N}$-terminal transactivation domain confers target gene specificity of hypoxia-inducible factors HIF-1alpha and HIF-2alpha. Molecular biology of the cell. 2007; 18: 4528-4542.

40. Li Q, Chen H, Huang X, Costa M. Effects of 12 metal ions on iron regulatory protein 1 (IRP-1) and hypoxia-inducible factor-1 alpha (HIF-1alpha) and HIF-regulated genes. Toxicology and applied pharmacology. 2006; 213:245-255.

41. Treins C, Giorgetti-Peraldi S, Murdaca J, MonthouelKartmann MN, Van Obberghen E. Regulation of hypoxiainducible factor (HIF)-1 activity and expression of HIF hydroxylases in response to insulin-like growth factor I. Mol Endocrinol. 2005; 19:1304-1317.

42. Salnikow K, An WG, Melillo G, Blagosklonny MV, Costa M. Nickel-induced transformation shifts the balance between HIF-1 and p53 transcription factors. Carcinogenesis. 1999; 20:1819-1823.
43. Cao C, Sun J, Zhang D, Guo X, Xie L, Li X, Wu D, Liu L. The Long Intergenic Noncoding RNA UFC1, A Target of MicroRNA 34a, Interacts With the mRNA Stabilizing Protein HuR to Increase Levels of beta-Catenin in HCC Cells. Gastroenterology. 2015; 148:415-26.e18.

44. Park MH, Choi KY, Jung Y, Min do S. Phospholipase D1 protein coordinates dynamic assembly of HIF-1alpha-PHDVHL to regulate HIF-1alpha stability. Oncotarget. 2014; 5:11857-11872. doi: 10.18632/oncotarget.2613.

45. Matouk IJ, Mezan S, Mizrahi A, Ohana P, Abu-Lail R, Fellig Y, Degroot N, Galun E, Hochberg A. The oncofetal H19 RNA connection: hypoxia, p53 and cancer. Biochimica et biophysica acta. 2010; 1803:443-451.

46. Yang F, Huo XS, Yuan SX, Zhang L, Zhou WP, Wang F, Sun SH. Repression of the long noncoding RNA-LET by histone deacetylase 3 contributes to hypoxia-mediated metastasis. Molecular cell. 2013; 49:1083-1096.

47. Maxwell PH, Pugh CW, Ratcliffe PJ. Activation of the HIF pathway in cancer. Current opinion in genetics \& development. 2001; 11:293-299.

48. Gutschner T, Hammerle M, Diederichs S. MALAT1 - a paradigm for long noncoding RNA function in cancer. $\mathrm{J}$ Mol Med (Berl). 2013; 91:791-801.

49. Kamat CD, Green DE, Curilla S, Warnke L, Hamilton JW, Sturup S, Clark C, Ihnat MA. Role of HIF signaling on tumorigenesis in response to chronic low-dose arsenic administration. Toxicological sciences. 2005; 86:248-257.

50. Waalkes MP, Qu W, Tokar EJ, Kissling GE, Dixon D. Lung tumors in mice induced by "whole-life" inorganic arsenic exposure at human-relevant doses. Archives of toxicology. 2014; 88:1619-1629.

51. Tokar EJ, Diwan BA, Ward JM, Delker DA, Waalkes MP. Carcinogenic effects of "whole-life" exposure to inorganic arsenic in CD1 mice. Toxicological sciences. $2011 ; 119: 73-83$.

52. Zhang A, Feng H, Yang G, Pan X, Jiang X, Huang X, Dong X, Yang D, Xie Y, Peng L, Jun L, Hu C, Jian L, et al. Unventilated indoor coal-fired stoves in Guizhou province, China: cellular and genetic damage in villagers exposed to arsenic in food and air. Environmental health perspectives. 2007; 115:653-658.

53. Zhang X, Wang C, Wang L, Du L, Wang S, Zheng G, Li W, Zhuang X, Dong Z. Detection of circulating Bmi-1 mRNA in plasma and its potential diagnostic and prognostic value for uterine cervical cancer. International journal of cancer. 2012; 131:165-172.

54. Zuberi M, Mir R, Das J, Ahmad I, Javid J, Yadav P, Masroor M, Ahmad S, Ray PC, Saxena A. Expression of serum miR-200a, miR-200b, and miR-200c as candidate biomarkers in epithelial ovarian cancer and their association with clinicopathological features. Clinical \& translational oncology. 2015; 17:779-787. 
55. Balkwill FR, Mantovani A. Cancer-related inflammation: common themes and therapeutic opportunities. Seminars in cancer biology. 2012; 22:33-40.

56. Li Y, Xu Y, Ling M, Yang Y, Wang S, Li Z, Zhou J, Wang X, Liu Q. mot-2-Mediated cross talk between nuclear factor-B and p53 is involved in arsenite-induced tumorigenesis of human embryo lung fibroblast cells. Environmental health perspectives. 2010; 118:936-942.
57. Lee TI, Johnstone SE, Young RA. Chromatin immunoprecipitation and microarray-based analysis of protein location. Nature protocols. 2006; 1:729-748. 